\title{
Resistance mechanisms to inhibitors of p53-MDM2 interactions in cancer therapy: can we overcome them?
}

\author{
Lucia Haronikova ${ }^{1 *}$, Ondrej Bonczek ${ }^{1,2}$, Pavlina Zatloukalova' ${ }^{1}$ Filip Kokas-Zavadil ${ }^{1}$, Martina Kucerikova ${ }^{1,3}$, \\ Philip J. Coates ${ }^{1}$, Robin Fahraeus ${ }^{1,2,4}$ and Borivoj Vojtesek ${ }^{1 *}$ (D)
}

${ }^{*}$ Correspondence: lucia.haronikova@mou.cz; vojtesek@mou.cz

1 RECAMO, Masaryk Memorial Cancer Institute, Zluty kopec 7, 65653 Brno, Czech Republic

Full list of author information is available at the end of the article

\begin{abstract}
Since the discovery of the first MDM2 inhibitors, we have gained deeper insights into the cellular roles of MDM2 and p53. In this review, we focus on MDM2 inhibitors that bind to the p53-binding domain of MDM2 and aim to disrupt the binding of MDM2 to p53. We describe the basic mechanism of action of these MDM2 inhibitors, such as nutlin-3a, summarise the determinants of sensitivity to MDM2 inhibition from p53-dependent and p53-independent points of view and discuss the problems with innate and acquired resistance to MDM2 inhibition. Despite progress in MDM2 inhibitor design and ongoing clinical trials, their broad use in cancer treatment is not fulfilling expectations in heterogenous human cancers. We assess the MDM2 inhibitor types in clinical trials and provide an overview of possible sources of resistance to MDM2 inhibition, underlining the need for patient stratification based on these aspects to gain better clinical responses, including the use of combination therapies for personalised medicine.
\end{abstract}

Keywords: p53, MDM2, MDM2 inhibitor, Nutlin-3a, Resistance, Combination therapy, Personalised medicine

\section{Introduction}

$\mathrm{p} 53$, the guardian of the genome, has been known for more than 40 years. Its importance as a tumour suppressor has been described from many points of view. In response to cellular stress stimuli, p53 acts as a transcriptional regulator of target genes in growth arrest/senescence and DNA damage repair, interacts with mitochondrial proteins involved in apoptosis, induces the immune response, and has many more roles [1-3]. In normal conditions, the p53 protein level is kept low by its main negative regulator, MDM2 (mouse double minute 2 homologue), which promotes p53 ubiquitination and its subsequent degradation $[4,5]$. After stress stimuli, the MDM2-p53 interaction is disrupted and p53 increases rapidly to activate p53 responses [6]. In a negative feedback loop, p53 transcriptionally upregulates MDM2 levels [7, 8]. The importance of the MDM2-p53 interaction is underlined by transgenic mice, where $M d m 2$-null mice show author(s) and the source, provide a link to the Creative Commons licence, and indicate if changes were made. The images or other third party material in this article are included in the article's Creative Commons licence, unless indicated otherwise in a credit line to the material. If material is not included in the article's Creative Commons licence and your intended use is not permitted by statutory regulation or exceeds the permitted use, you will need to obtain permission directly from the copyright holder. To view a copy of this licence, visit http:// creativecommons.org/licenses/by/4.0/. 
embryonic lethality due to massive apoptosis, which is rescued by concomitant $\operatorname{Tr} p 53$ deletion $[9,10]$.

TP53 is the most commonly mutated gene in human cancer. Although p53 retains its wild-type form in around $50 \%$ of cancers, its function is compromised by other means in most of these tumours $[11,12]$. Overexpression of MDM2 by gene amplification or single nucleotide polymorphism is documented in many cancer types, and the occurrence of p53 mutations and overexpression of MDM2 are usually mutually exclusive, supporting the notion that MDM2 overexpression is responsible for driving the cancer phenotype by abolishing p53 activity [13-15]. Other MDM2 functions may also contribute to its oncogenic effects, such as its pro-angiogenic activity, involvement in chromosome instability, degradation of cell cycle regulators, and degradation of E-cadherin leading to epithelial-mesenchymal transition (EMT) [16-22]. New findings also suggest that MDM2 overexpression confers resistance to conventional chemotherapy [23]. The use of compounds that disrupt the p53-MDM2 interaction is therefore a rational approach to activate the p53 response in cancer cells in which p53 activity is compromised by mechanisms other than TP53 mutation.

Initial structural characterisation of the p53-MDM2 binding interface revealed that the MDM2 N-terminus possesses a deep hydrophobic pocket occupied by side chains of three amino-acid residues (Phe19, Trp23, Leu26) in the alpha-helical transactivation domain of p53 [24]. The development of small molecule inhibitors and stapled peptides that bind this pocket is mainly based on mimicking these three amino acid side chains and later inhibitors provide one additional binding site to achieve higher affinity [2527]. This approach was shown to inhibit the p53-MDM2 interaction and to activate p53 responses. Nutlins were the first class of small inhibitor molecules [28] and a racemic mixture was used initially (referred to as nutlin-3 in the text). Subsequently, an active enantiomer called nutlin-3a became more widely used (see MDM2 inhibitor types and clinical trials for more details). From a structural point of view, MDM2 displays high plasticity, and the binding of p53 and some small molecule inhibitors induce ordering of the MDM2 N-terminal domain [29-32]. A second responsive site was identified in the $\mathrm{N}$-terminal domain for nutlin-3 [33]. Importantly, inhibitors that bind the MDM2 N-terminal domain do not disturb the ubiquitination activity of the MDM2 RING domain present in the C-terminus [34].

In this review, we focus on MDM2 inhibitors that were designed to disrupt MDM2p53 binding and thus activate wild-type p53, such as nutlin. Many small molecule inhibitors have entered clinical trials, often in combination with other therapeutics. Patients were originally stratified for MDM2 inhibitor treatment based on their p53 status or MDM2 amplification [35]. Although activation of wild-type p53 is almost universal after MDM2 inhibition, the outcomes range from cell cycle arrest to apoptosis, depending on cell type, dose and time of exposure [36-41]. Therefore, to stratify patients who will benefit from MDM2 inhibition, it is necessary to identify criteria other than simple p53 wild-type/mutation status that govern the cellular response to such treatment. The precise characterisation of tumour genetic background and cancer type should improve the response to MDM2 inhibition and could help to design appropriate combination therapies. Improved schedules and doses of treatment combinations should also help to mitigate problems with toxicity and/or acquired resistance. 


\section{Types of MDM2 inhibitors and clinical trials}

The first small molecules that inhibit MDM2/p53 binding were synthesised by Vassilev et al. [28] as racemic mixtures of compounds called nutlin 1-3, from which the most potent binding was reported by enantiomer $3 \mathrm{a}\left(\mathrm{IC}_{50} \sim 90 \mathrm{nM}\right)$ (Fig. 1). All these early

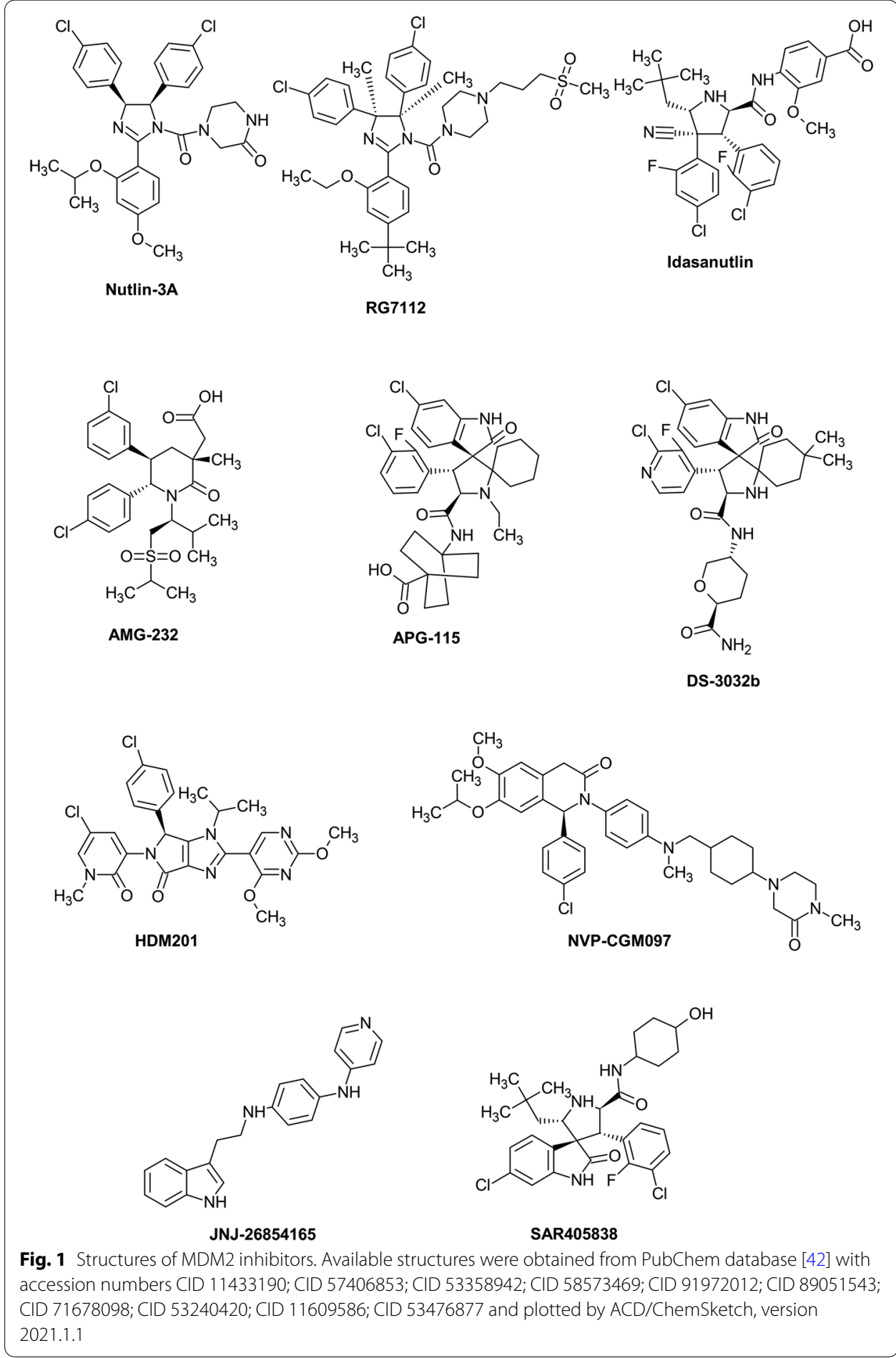


nutlins are cis-imidazoline analogues that mimic the natural helical order of peptides, and three side groups of imidazoline scaffold exactly fit into the MDM2 groove that binds to p53. Although early nutlins showed cellular activity and confirmed the concept of MDM2 inhibition to activate wild-type p53, they lack the required pharmacological properties for clinical development and trials.

The first clinically tested molecule was RG7112 $\left(\mathrm{IC}_{50} \sim 20 \mathrm{nM}\right)$. Compared to nutlin-3a, it differs in substitution of the imidazoline core and replacement of the methoxy group by a tert-butyl group [43]. RG7112 was the first MDM2 inhibitor clinically assessed in a trial registered with EudraCT (2009-015522-10) in patients with MDM2amplified liposarcomas [35]. Clinical activity as monotherapy or in combination with cytotoxic drugs such as cytarabine or doxorubicin was also assessed in patients with solid tumours, haematological neoplasms or sarcomas in several phase I and Ib clinical trials (Table 1). A clinical response was achieved particularly against AML (NCT00623870), even in cases carrying p53 mutations [44]. However, RG7112 showed poor tolerability at the required high doses, with relatively severe haematological and gastrointestinal toxicities that hampered achieving appropriate clinical effects, and RG7112 is not currently under clinical assessment.

Further research left the imidazoline backbone and focussed on pyrrolidine derivatives, which made it possible to improve biological parameters and reduce the effective dose. Idasanutlin (RG7388, $\mathrm{RO} 5503781 ; \mathrm{IC}_{50}=6 \mathrm{nM}$ ) is a potent and selective candidate with a better pharmacokinetic profile than RG7112 [45]. Patient responses were evaluated in monotherapy or in combination with chemotherapeutic agents, or with venetoclax (BCL2 inhibitor), posaconazole (CYP3A4 (cytochrome P450 3A4)) inhibitor) or cobimetinib (MEK inhibitor) in haematological malignancies (Table 1). A study using idasanutlin in combination with cytarabine (NCT01773408) showed good tolerability and concluded that MDM2 protein is a predictive biomarker to identify patients who might benefit from idasanutlin-based therapy [46]. The combined effect of idasanutlin and cytarabine was clinically assessed in a global phase III study (NCT02545283) in patients with AML, but the study was terminated for futility based on efficacy results. Clinical trials evaluating idasanutlin in combination with other agents are summarised in Table 1. Several other idasanutlin-based trials are currently in progress (Table 2).

A de novo design of a piperidinone scaffold and addition of an $\mathrm{N}$-alkyl substituent led to AM-8553, a predecessor of AMG-232. The final structure of AMG-232 is a sulfone piperidinone derivative with two isopropyl groups on the sulfone side chain, and has excellent pharmacokinetic properties $\left(\mathrm{IC}_{50}=10 \mathrm{nM}\right)$ [47, 48]. AMG-232 showed clinical activity as monotherapy [49] and in combination with trametinib (MEK inhibitor) [50] and/or the BRAF inhibitor dabrafenib [51] (Table 1). Several trials assessing AMG232 in combination with various agents and radiation therapy are currently recruiting (Table 2).

Promising prospects were given to spirooxindole-containing MDM2 inhibitors AA115/APG-115, with good chemical stability and excellent oral pharmacokinetics. Following oral administration, tumour regression has been observed in xenograft models of acute leukaemia and other cancers, leading to its entry into clinical development [52, 53]. To date, only one study (NCT02935907) assessing APG-115 as monotherapy in patients with advanced solid tumours has been completed [54]; APG-115 was 
Table 1 List of MDM2-p53 inhibitors in completed clinical trials

\begin{tabular}{|c|c|c|c|c|c|c|c|c|}
\hline Drug & Disease & $\begin{array}{l}\text { Combination } \\
\text { with }\end{array}$ & Action & Phase & Status & Trial nr & Sponzor & Time \\
\hline \multirow[t]{6}{*}{$\begin{array}{l}\text { RG/112 } \\
\text { (RO5045337) }\end{array}$} & $\begin{array}{l}\text { Advanced } \\
\text { solid } \\
\text { tumors }\end{array}$ & & & I & $\begin{array}{l}\text { Com- } \\
\text { pleted }\end{array}$ & NCT00559533* & $\begin{array}{l}\text { Hoff- } \\
\text { mann- } \\
\text { LaRoche }\end{array}$ & $\begin{array}{l}2007- \\
2012\end{array}$ \\
\hline & $\begin{array}{l}\text { Hema- } \\
\text { tologic } \\
\text { neoplasm }\end{array}$ & & & 1 & $\begin{array}{l}\text { Com- } \\
\text { pleted }\end{array}$ & NCT00623870* & $\begin{array}{l}\text { Hoff- } \\
\text { mann-La } \\
\text { Roche }\end{array}$ & $\begin{array}{l}2008- \\
2012\end{array}$ \\
\hline & $\begin{array}{l}\text { Solid } \\
\text { tumors }\end{array}$ & & & 1 & $\begin{array}{l}\text { Com- } \\
\text { pleted }\end{array}$ & NCT01164033* & $\begin{array}{l}\text { Hoff- } \\
\text { mann-La } \\
\text { Roche }\end{array}$ & $\begin{array}{l}2010- \\
2013\end{array}$ \\
\hline & Sarcoma & Doxorubicin & $\begin{array}{l}\text { DNA } \\
\text { dam- } \\
\text { age }\end{array}$ & $\mathrm{Ib}$ & $\begin{array}{l}\text { Com- } \\
\text { pleted }\end{array}$ & NCT01605526* & $\begin{array}{l}\text { Hoff- } \\
\text { mann-La } \\
\text { Roche }\end{array}$ & $\begin{array}{l}2012- \\
2013\end{array}$ \\
\hline & $\begin{array}{l}\text { Acute mye- } \\
\text { logenous } \\
\text { leukemia } \\
\text { (AML) }\end{array}$ & Cytarabine & $\begin{array}{l}\text { DNA } \\
\text { dam- } \\
\text { age }\end{array}$ & $\mathrm{lb}$ & $\begin{array}{l}\text { Com- } \\
\text { pleted }\end{array}$ & NCT01635296* & $\begin{array}{l}\text { Hoff- } \\
\text { mann-La } \\
\text { Roche }\end{array}$ & $\begin{array}{l}2012- \\
2013\end{array}$ \\
\hline & $\begin{array}{l}\text { Exten- } \\
\text { sion study } \\
\text { of studies } \\
\text { marked } \\
\text { with* }\end{array}$ & & & I & $\begin{array}{l}\text { Com- } \\
\text { pleted }\end{array}$ & NCT01677780 & $\begin{array}{l}\text { Hoff- } \\
\text { mann-La } \\
\text { Roche }\end{array}$ & $\begin{array}{l}2012- \\
2017\end{array}$ \\
\hline \multirow[t]{7}{*}{$\begin{array}{l}\text { Idasanut- } \\
\text { lin (RG7388) }\end{array}$} & $\begin{array}{l}\text { Advanced } \\
\text { malignan- } \\
\text { cies, except } \\
\text { leukemia }\end{array}$ & & & I & $\begin{array}{l}\text { Com- } \\
\text { pleted }\end{array}$ & NCT01462175 & $\begin{array}{l}\text { Hoff- } \\
\text { mann-La } \\
\text { Roche }\end{array}$ & $\begin{array}{l}2011- \\
2014\end{array}$ \\
\hline & $\begin{array}{l}\text { Solid } \\
\text { tumors }\end{array}$ & & & I & $\begin{array}{l}\text { Com- } \\
\text { pleted }\end{array}$ & NCT03362723 & $\begin{array}{l}\text { Hoff- } \\
\text { mann-La } \\
\text { Roche }\end{array}$ & $\begin{array}{l}2017- \\
2019\end{array}$ \\
\hline & $\begin{array}{l}\text { Acute mye- } \\
\text { logenous } \\
\text { leukemia }\end{array}$ & $\begin{array}{l}\text { Idarubicin } \\
\text { Daunorubicin } \\
\text { Cytarabine }\end{array}$ & $\begin{array}{l}\text { DNA } \\
\text { dam- } \\
\text { age } \\
\text { DNA } \\
\text { dam- } \\
\text { age } \\
\text { DNA } \\
\text { dam- } \\
\text { age }\end{array}$ & $|/| b$ & $\begin{array}{l}\text { Com- } \\
\text { pleted }\end{array}$ & NCT01773408 & $\begin{array}{l}\text { Hoff- } \\
\text { mann-La } \\
\text { Roche }\end{array}$ & $\begin{array}{l}2013- \\
2016\end{array}$ \\
\hline & $\begin{array}{l}\text { Relapsed } \\
\text { and refrac- } \\
\text { tory AML }\end{array}$ & Cytarabine & $\begin{array}{l}\text { DNA } \\
\text { dam- } \\
\text { age }\end{array}$ & III & $\begin{array}{l}\text { Termi- } \\
\text { nated }\end{array}$ & NCT02545283 & $\begin{array}{l}\text { Hoff- } \\
\text { mann-La } \\
\text { Roche }\end{array}$ & $\begin{array}{l}2012- \\
2020\end{array}$ \\
\hline & $\begin{array}{l}\text { Non- } \\
\text { Hodgkin's } \\
\text { lymphoma }\end{array}$ & $\begin{array}{l}\text { Obinutu- } \\
\text { zumab } \\
\text { Rituximab }\end{array}$ & $\begin{array}{l}\text { Anti- } \\
\text { CD20 } \\
\text { Anti- } \\
\text { CD20 }\end{array}$ & $\mathrm{I} / \mathrm{lb}$ & $\begin{array}{l}\text { Termi- } \\
\text { nated }\end{array}$ & NCT02624986 & $\begin{array}{l}\text { Hoff- } \\
\text { mann-La } \\
\text { Roche }\end{array}$ & $\begin{array}{l}2015- \\
2019\end{array}$ \\
\hline & $\begin{array}{l}\text { Relapsed } \\
\text { and refrac- } \\
\text { tory AML }\end{array}$ & Venetoclax & $\begin{array}{l}\text { BCL-2 } \\
\text { inhibi- } \\
\text { tor }\end{array}$ & $\mathrm{lb}$ & $\begin{array}{l}\text { Com- } \\
\text { pleted }\end{array}$ & NCT02670044 & $\begin{array}{l}\text { Hoff- } \\
\text { mann-La } \\
\text { Roche }\end{array}$ & $\begin{array}{l}2016- \\
2020\end{array}$ \\
\hline & $\begin{array}{l}\text { Relapsed } \\
\text { and } \\
\text { refractory } \\
\text { follicular } \\
\text { lymphoma, } \\
\text { relapsed } \\
\text { and refrac- } \\
\text { tory diffuse } \\
\text { large B-cell } \\
\text { lymphoma }\end{array}$ & $\begin{array}{l}\text { Obinutu- } \\
\text { zumab } \\
\text { Venetoclax } \\
\text { Rituximab }\end{array}$ & $\begin{array}{l}\text { Anti- } \\
\text { CD20 } \\
\text { BCL-2 } \\
\text { inhibi- } \\
\text { tor } \\
\text { Anti- } \\
\text { CD20 }\end{array}$ & $\mid \mathrm{b} / \|$ & $\begin{array}{l}\text { Termi- } \\
\text { nated }\end{array}$ & NCT03135262 & $\begin{array}{l}\text { Hoff- } \\
\text { mann-La } \\
\text { Roche }\end{array}$ & $\begin{array}{l}2018- \\
2020\end{array}$ \\
\hline
\end{tabular}


Table 1 (continued)

\begin{tabular}{|c|c|c|c|c|c|c|c|c|}
\hline Drug & Disease & $\begin{array}{l}\text { Combination } \\
\text { with }\end{array}$ & Action & Phase & Status & Trial nr & Sponzor & Time \\
\hline & $\begin{array}{l}\text { Acute mye- } \\
\text { logenous } \\
\text { leukemia }\end{array}$ & $\begin{array}{l}\text { Cytarabine } \\
\text { Daunorubicin }\end{array}$ & $\begin{array}{l}\text { DNA } \\
\text { dam- } \\
\text { age } \\
\text { DNA } \\
\text { dam- } \\
\text { age }\end{array}$ & $|\mathrm{b} /| \mathrm{I}$ & $\begin{array}{l}\text { Com- } \\
\text { pleted }\end{array}$ & NCT03850535 & $\begin{array}{l}\text { Hoff- } \\
\text { mann-La } \\
\text { Roche }\end{array}$ & $\begin{array}{l}2019- \\
2020\end{array}$ \\
\hline \multirow[t]{3}{*}{$\begin{array}{l}\text { AMG- } \\
232 \text { (KRT-232) }\end{array}$} & $\begin{array}{l}\text { Advanced } \\
\text { solid } \\
\text { tumors, } \\
\text { multiple } \\
\text { myeloma }\end{array}$ & & & I & $\begin{array}{l}\text { Com- } \\
\text { pleted }\end{array}$ & NCT01723020 & Amgen & $\begin{array}{l}2012- \\
2017\end{array}$ \\
\hline & $\begin{array}{l}\text { Acute mye- } \\
\text { logenous } \\
\text { leukemia }\end{array}$ & Trametinib & $\begin{array}{l}\text { MEK } \\
\text { inhibi- } \\
\text { tor }\end{array}$ & 1 & $\begin{array}{l}\text { Com- } \\
\text { pleted }\end{array}$ & NCT02016729 & $\begin{array}{l}\text { Kartos } \\
\text { Therapeu- } \\
\text { tics, Inc. }\end{array}$ & $\begin{array}{l}2014- \\
2017\end{array}$ \\
\hline & $\begin{array}{l}\text { Metastatic } \\
\text { melanoma }\end{array}$ & $\begin{array}{l}\text { Trametinib } \\
\text { Dabrafenib }\end{array}$ & $\begin{array}{l}\text { MEK } \\
\text { inhibi- } \\
\text { tor } \\
\text { BRAF } \\
\text { inhibi- } \\
\text { tor }\end{array}$ & $\mathrm{lb} / \mathrm{lla}$ & $\begin{array}{l}\text { Com- } \\
\text { pleted }\end{array}$ & NCT02110355 & $\begin{array}{l}\text { Kartos } \\
\text { Therapeu- } \\
\text { tics, Inc. }\end{array}$ & $\begin{array}{l}2014- \\
2018\end{array}$ \\
\hline $\begin{array}{l}\text { APG-115 } \\
\text { (AA-115) }\end{array}$ & $\begin{array}{l}\text { Advanced } \\
\text { solid } \\
\text { tumors. } \\
\text { Lympho- } \\
\text { mas }\end{array}$ & & & 1 & $\begin{array}{l}\text { Com- } \\
\text { pleted }\end{array}$ & NCT02935907 & $\begin{array}{l}\text { Ascent- } \\
\text { age } \\
\text { Pharma } \\
\text { Group, } \\
\text { Inc. }\end{array}$ & $\begin{array}{l}2016- \\
2019\end{array}$ \\
\hline CGM097 & $\begin{array}{l}\text { Advanced } \\
\text { solid } \\
\text { tumors } \\
\text { with } \\
\text { TP53wt }\end{array}$ & & & I & $\begin{array}{l}\text { Com- } \\
\text { pleted }\end{array}$ & NCT01760525 & $\begin{array}{l}\text { Novartis } \\
\text { Pharma- } \\
\text { ceuticals }\end{array}$ & $\begin{array}{l}2013- \\
2019\end{array}$ \\
\hline HDM201 & $\begin{array}{l}\text { Liposar- } \\
\text { coma }\end{array}$ & Ribociclib & $\begin{array}{l}\text { CDKin- } \\
\text { hibitor }\end{array}$ & $\mid \mathrm{b} / \|$ & $\begin{array}{l}\text { Com- } \\
\text { pleted }\end{array}$ & NCT02343172 & $\begin{array}{l}\text { Novartis } \\
\text { Pharma- } \\
\text { ceuticals }\end{array}$ & $\begin{array}{l}2015- \\
2019\end{array}$ \\
\hline \multirow[t]{4}{*}{$\begin{array}{l}\text { DS- } \\
\text { 3032b (Mila- } \\
\text { demetan) }\end{array}$} & $\begin{array}{l}\text { Advanced } \\
\text { solid } \\
\text { tumors, } \\
\text { lymphomas }\end{array}$ & & & I & $\begin{array}{l}\text { Com- } \\
\text { pleted }\end{array}$ & NCT01877382 & $\begin{array}{l}\text { Daiichi } \\
\text { Sankyo } \\
\text { Co., Ltd. }\end{array}$ & $\begin{array}{l}2013- \\
2020\end{array}$ \\
\hline & $\begin{array}{l}\text { Relapsed } \\
\text { and refrac- } \\
\text { tory AML }\end{array}$ & & & I & $\begin{array}{l}\text { Com- } \\
\text { pleted }\end{array}$ & NCT03671564 & $\begin{array}{l}\text { Daiichi } \\
\text { Sankyo } \\
\text { Co., Ltd. }\end{array}$ & $\begin{array}{l}2018- \\
2019\end{array}$ \\
\hline & $\begin{array}{l}\text { Acute mye- } \\
\text { logenous } \\
\text { leukemia }\end{array}$ & Quizartinib & $\begin{array}{l}\text { Tyros- } \\
\text { ine } \\
\text { kinase } \\
\text { inhibi- } \\
\text { tor }\end{array}$ & । & $\begin{array}{l}\text { Termi- } \\
\text { nated }\end{array}$ & NCT03552029 & $\begin{array}{l}\text { Daiichi } \\
\text { Sankyo } \\
\text { Co., Ltd. }\end{array}$ & $\begin{array}{l}2018- \\
2021\end{array}$ \\
\hline & $\begin{array}{l}\text { Acute mye- } \\
\text { logenous } \\
\text { leukemia, } \\
\text { myelod- } \\
\text { ysplastic } \\
\text { syndromes }\end{array}$ & 5-Azacitidine & $\begin{array}{l}\text { DNA } \\
\text { dam- } \\
\text { age }\end{array}$ & I & $\begin{array}{l}\text { Termi- } \\
\text { nated }\end{array}$ & NCT02319369 & $\begin{array}{l}\text { Daiichi } \\
\text { Sankyo } \\
\text { Co., Ltd. }\end{array}$ & $\begin{array}{l}2014- \\
2021\end{array}$ \\
\hline \multirow[t]{2}{*}{ ALRN-6924 } & $\begin{array}{l}\text { Advanced } \\
\text { solid } \\
\text { tumors, } \\
\text { lymphomas }\end{array}$ & & & |/Ila & $\begin{array}{l}\text { Com- } \\
\text { pleted }\end{array}$ & NCT02264613 & $\begin{array}{l}\text { Aileron } \\
\text { Therapeu- } \\
\text { tics }\end{array}$ & $\begin{array}{l}2014- \\
2020\end{array}$ \\
\hline & $\begin{array}{l}\text { Acute mye- } \\
\text { logenous } \\
\text { leukemia, } \\
\text { myelod- } \\
\text { ysplastic } \\
\text { syndromes }\end{array}$ & Cytarabine & $\begin{array}{l}\text { DNA } \\
\text { dam- } \\
\text { age }\end{array}$ & $\mathrm{l} / \mathrm{lb}$ & $\begin{array}{l}\text { Com- } \\
\text { pleted }\end{array}$ & NCT02909972 & $\begin{array}{l}\text { Aileron } \\
\text { Therapeu- } \\
\text { tics }\end{array}$ & $\begin{array}{l}2016- \\
2019\end{array}$ \\
\hline
\end{tabular}


Table 1 (continued)

\begin{tabular}{|c|c|c|c|c|c|c|c|c|}
\hline Drug & Disease & $\begin{array}{l}\text { Combination } \\
\text { with }\end{array}$ & Action & Phase & Status & Trial nr & Sponzor & Time \\
\hline JNJ-26854165 & $\begin{array}{l}\text { Advanced } \\
\text { of refrac- } \\
\text { tory solid } \\
\text { tumors }\end{array}$ & & & & $\begin{array}{l}\text { Com- } \\
\text { pleted }\end{array}$ & NCT00676910 & $\begin{array}{l}\text { John- } \\
\text { son \& } \\
\text { Johnson } \\
\text { Pharma- } \\
\text { ceutical } \\
\text { Research } \\
\text { \& Devel- } \\
\text { opment, } \\
\text { L.L.C. }\end{array}$ & $\begin{array}{l}2006- \\
2010\end{array}$ \\
\hline SAR405838 & $\begin{array}{l}\text { Solid } \\
\text { tumors }\end{array}$ & Pimasertib & $\begin{array}{l}\text { MEK } \\
\text { inhibi- } \\
\text { tor }\end{array}$ & I & $\begin{array}{l}\text { Com- } \\
\text { pleted }\end{array}$ & NCT01985191 & Sanofi & $\begin{array}{l}2013- \\
2016\end{array}$ \\
\hline
\end{tabular}

*These studies were extended by clinical trial NCT01677780

well tolerated, had manageable adverse events and the maximum tolerated dose was recommended for phase II. Preliminary results from a phase II study in combination with pembrolizumab (PD-1 blockade) seem promising for patients with metastatic melanoma or advanced solid tumours resistant to previous immuno-oncologic treatment (NCT03611868) [55]. Other clinical trials of APG-115 are ongoing.

From Boehringer Ingelheim came a compound with a multi-cyclic core called BI907828. The first pharmacokinetic trials across species showed high permeability, good physiological solubility and low systemic clearance together with a promising low human efficacious dose [56]. BI-907828 showed significant anti-tumour activity for patient-derived xenografts from dedifferentiated liposarcomas [57] and patients are recruited to two clinical trials in combination therapy.

NVP-CGM097 (Novartis) is a representative small molecule with a dihydroisoquinolinone scaffold about four times more potent than nutlin-3a $[58,59]$. To date only a phase I dose escalation study in patients with advanced solid tumours has been completed (NCT01750525). Despite haematologic toxicity with delayed-onset thrombocytopenia frequently observed, the tolerability of NVP-CGM097 appeared manageable and the disease control rate was 39\% [60]. At the moment there are no planned studies reported.

Another candidate from Novartis, siremadlin (NVP-HDM201), is an imidazolopyrrolidinone analogue, and experimental data on xenografts showed up to tenfold potentiation compared to NVP-CGM097 [61]. The first data of combined treatment with midostaurin of AML cells harbouring FLT3-ITD (Fms related receptor tyrosine kinase 3 internal tandem duplication) look promising [62]. In clinical trials, NVPHDM201 showed promising anti-leukaemic activity [63] in patients with wild-type TP53 (NCT02143635), and clinical safety and efficacy in combination with LEE011 (CDK4/6 inhibitor) were confirmed in patients with liposarcoma (NCT02343172) [64]. Additional clinical studies using NVP-HDM201 are ongoing.

The dispiropyrrolidine based compound milademetan (DS-3032b), demonstrated in vitro and in vivo reactivation of p53 signalling in neuroblastoma cells, reducing proliferative capacity and causing cytotoxicity [65]. Clinically, DS-3032b as a single agent had an acceptable safety profile and clinical benefit was seen in patients with 
Table 2 List of MDM2-p53 inhibitors in ongoing clinical trials

\begin{tabular}{|c|c|c|c|c|c|c|c|c|}
\hline Drug & Disease & $\begin{array}{l}\text { Combination } \\
\text { with }\end{array}$ & & Phase & Status & Trial nr & Sponzor & $\begin{array}{l}\text { Start } \\
\text { date }\end{array}$ \\
\hline \multirow[t]{3}{*}{$\begin{array}{l}\text { Idasa- } \\
\text { nutlin } \\
\text { (RG7388) }\end{array}$} & $\begin{array}{l}\text { Breast } \\
\text { cancer }\end{array}$ & Atezolizumab & $\begin{array}{l}\text { Anti-PD- } \\
\text { L1 }\end{array}$ & $|/| \mid$ & $\begin{array}{l}\text { Active, } \\
\text { not } \\
\text { recruit- } \\
\text { ing }\end{array}$ & NCT03566485 & $\begin{array}{l}\text { Vanderbilt- } \\
\text { Ingram Can- } \\
\text { cer Center }\end{array}$ & 2018 \\
\hline & $\begin{array}{l}\text { Acute mye- } \\
\text { logenous } \\
\text { leukemia } \\
\text { (AML), } \\
\text { acute lym- } \\
\text { phocytic } \\
\text { leukemia, } \\
\text { neuroblas- } \\
\text { toma, solid } \\
\text { tumors }\end{array}$ & $\begin{array}{l}\text { Cyclophospha- } \\
\text { mide } \\
\text { Topotecan } \\
\text { Fludarabine } \\
\text { Cytarabine }\end{array}$ & & $|/| \mid$ & $\begin{array}{l}\text { Recruit- } \\
\text { ing }\end{array}$ & NCT04029688 & $\begin{array}{l}\text { Hoffmann- } \\
\text { La Roche }\end{array}$ & 2020 \\
\hline & $\begin{array}{l}\text { Relapsed } \\
\text { multiple } \\
\text { myeloma }\end{array}$ & $\begin{array}{l}\text { Ixazomib } \\
\text { Dexametha- } \\
\text { sone } \\
\text { Venetoclax }\end{array}$ & & $|/| \mid$ & $\begin{array}{l}\text { Active, } \\
\text { not } \\
\text { recruit- } \\
\text { ing }\end{array}$ & NCT02633059 & Mayo Clinic & 2021 \\
\hline \multirow[t]{6}{*}{$\begin{array}{l}\text { AMG- } \\
232 \text { (KRT- } \\
232 \text { ) }\end{array}$} & $\begin{array}{l}\text { Acute mye- } \\
\text { logenous } \\
\text { leukemia, } \\
\text { relapsed } \\
\text { and refrac- } \\
\text { tory AML }\end{array}$ & Decitabine & $\begin{array}{l}\text { DNA } \\
\text { damage }\end{array}$ & I & $\begin{array}{l}\text { Recruit- } \\
\text { ing }\end{array}$ & NCT03041688 & $\begin{array}{l}\text { National } \\
\text { Cancer } \\
\text { Institute }\end{array}$ & 2017 \\
\hline & $\begin{array}{l}\text { Soft tissue } \\
\text { sarcoma }\end{array}$ & $\begin{array}{l}\text { Radiation } \\
\text { therapy }\end{array}$ & & $\mathrm{lb}$ & $\begin{array}{l}\text { Recruit- } \\
\text { ing }\end{array}$ & NCT03217266 & $\begin{array}{l}\text { National } \\
\text { Cancer } \\
\text { Institute }\end{array}$ & 2017 \\
\hline & $\begin{array}{l}\text { Poly- } \\
\text { cythemia } \\
\text { vera }\end{array}$ & Ruxolitinib & $\begin{array}{l}\text { TK inhibi- } \\
\text { tor }\end{array}$ & $\|$ & $\begin{array}{l}\text { Active, } \\
\text { not } \\
\text { recruit- } \\
\text { ing }\end{array}$ & NCT03669965 & $\begin{array}{l}\text { Kartos } \\
\text { Therapeu- } \\
\text { tics, Inc }\end{array}$ & 2018 \\
\hline & $\begin{array}{l}\text { Relapsed } \\
\text { multiple } \\
\text { myeloma }\end{array}$ & $\begin{array}{l}\text { Carfilzomib } \\
\text { Dexametha- } \\
\text { sone } \\
\text { Lenalidomide }\end{array}$ & $\begin{array}{l}\text { Pro- } \\
\text { teosome } \\
\text { inhibitor } \\
\text { Chemo- } \\
\text { therapy } \\
\text { Chemo- } \\
\text { therapy }\end{array}$ & I & $\begin{array}{l}\text { Recruit- } \\
\text { ing }\end{array}$ & NCT03031730 & $\begin{array}{l}\text { National } \\
\text { Cancer } \\
\text { Institute }\end{array}$ & 2017 \\
\hline & Brain cancer & $\begin{array}{l}\text { Radiation } \\
\text { therapy }\end{array}$ & & I & $\begin{array}{l}\text { Recruit- } \\
\text { ing }\end{array}$ & NCT03107780 & $\begin{array}{l}\text { National } \\
\text { Cancer } \\
\text { Institute }\end{array}$ & 2018 \\
\hline & $\begin{array}{l}\text { Acute mye- } \\
\text { logenous } \\
\text { leukemia }\end{array}$ & $\begin{array}{l}\text { Cytarabine } \\
\text { Idarubicin } \mathrm{HCl}\end{array}$ & $\begin{array}{l}\text { DNA } \\
\text { damage } \\
\text { DNA } \\
\text { damage }\end{array}$ & $\mathrm{lb}$ & $\begin{array}{l}\text { Recruit- } \\
\text { ing }\end{array}$ & NCT04190550 & $\begin{array}{l}\text { National } \\
\text { Cancer } \\
\text { Institute }\end{array}$ & 2020 \\
\hline \multirow[t]{2}{*}{$\begin{array}{l}\text { APG- } \\
115 \text { (AA- } \\
115)\end{array}$} & $\begin{array}{l}\text { Metastatic } \\
\text { melanomas, } \\
\text { advanced } \\
\text { solid } \\
\text { tumors }\end{array}$ & $\begin{array}{l}\text { Pembroli- } \\
\text { zumab }\end{array}$ & $\begin{array}{l}\text { Anti- } \\
\text { PD-1 }\end{array}$ & $|\mathrm{b} /| \mid$ & $\begin{array}{l}\text { Recruit- } \\
\text { ing }\end{array}$ & NCT03611868 & $\begin{array}{l}\text { Ascentage } \\
\text { Pharma } \\
\text { Group, Inc. }\end{array}$ & 2018 \\
\hline & $\begin{array}{l}\text { Salivary } \\
\text { gland carci- } \\
\text { noma }\end{array}$ & Carboplatin & $\begin{array}{l}\text { DNA } \\
\text { damage }\end{array}$ & $|/| \mid$ & $\begin{array}{l}\text { Recruit- } \\
\text { ing }\end{array}$ & NCT03781986 & $\begin{array}{l}\text { Ascentage } \\
\text { Pharma } \\
\text { Group, Inc. }\end{array}$ & 2019 \\
\hline
\end{tabular}


Table 2 (continued)

\begin{tabular}{|c|c|c|c|c|c|c|c|c|}
\hline Drug & Disease & $\begin{array}{l}\text { Combination } \\
\text { with }\end{array}$ & & Phase & Status & Trial nr & Sponzor & $\begin{array}{l}\text { Start } \\
\text { date }\end{array}$ \\
\hline & $\begin{array}{l}\text { Acute mye- } \\
\text { logenous } \\
\text { leukemia } \\
\text { (AML), } \\
\text { acute lym- } \\
\text { phocytic } \\
\text { leukemia, } \\
\text { neuroblas- } \\
\text { toma }\end{array}$ & $\begin{array}{l}\text { Azacitidine } \\
\text { Cytarabine }\end{array}$ & $\begin{array}{l}\text { DNA } \\
\text { damage } \\
\text { DNA } \\
\text { damage }\end{array}$ & lb & $\begin{array}{l}\text { Recruit- } \\
\text { ing }\end{array}$ & NCT04275518 & $\begin{array}{l}\text { Ascentage } \\
\text { Pharma } \\
\text { Group, Inc. }\end{array}$ & 2020 \\
\hline & $\begin{array}{l}\text { Acute mye- } \\
\text { logenous } \\
\text { leukemia }\end{array}$ & 5-azacitidine & $\begin{array}{l}\text { DNA } \\
\text { damage }\end{array}$ & $\mathrm{lb} / \mathrm{ll}$ & $\begin{array}{l}\text { Recruit- } \\
\text { ing }\end{array}$ & NCT04358393 & $\begin{array}{l}\text { Ascentage } \\
\text { Pharma } \\
\text { Group, Inc. }\end{array}$ & 2020 \\
\hline & $\begin{array}{l}\text { Liposar- } \\
\text { coma, } \\
\text { advanced } \\
\text { solid } \\
\text { tumors }\end{array}$ & Toripalimab & $\begin{array}{l}\text { Anti- } \\
\text { PD-1 }\end{array}$ & $|\mathrm{b} /| \mathrm{I}$ & $\begin{array}{l}\text { Not yet } \\
\text { recruit- } \\
\text { ing }\end{array}$ & NCT04785196 & $\begin{array}{l}\text { Ascentage } \\
\text { Pharma } \\
\text { Group, Inc. }\end{array}$ & 2021 \\
\hline & $\begin{array}{l}\text { T-prolym- } \\
\text { phocytic } \\
\text { leukemia }\end{array}$ & APG-2575 & & Ila & $\begin{array}{l}\text { Not yet } \\
\text { recruit- } \\
\text { ing }\end{array}$ & NCT04496349 & $\begin{array}{l}\text { Ascentage } \\
\text { Pharma } \\
\text { Group, Inc. }\end{array}$ & 2021 \\
\hline \multirow[t]{2}{*}{ B1907828 } & $\begin{array}{l}\text { Solid } \\
\text { tumors }\end{array}$ & & & $\mathrm{la} / \mathrm{lb}$ & $\begin{array}{l}\text { Recruit- } \\
\text { ing }\end{array}$ & NCT03449381 & $\begin{array}{l}\text { Boehringer } \\
\text { Ingelheim }\end{array}$ & 2018 \\
\hline & $\begin{array}{l}\text { Solid } \\
\text { tumors }\end{array}$ & $\begin{array}{l}\text { Ezanbenlimab } \\
\text { B1754111 }\end{array}$ & $\begin{array}{l}\text { Anti- } \\
\text { PD-1 } \\
\text { Anti- } \\
\text { LAG-3 }\end{array}$ & $\mathrm{la} / \mathrm{lb}$ & $\begin{array}{l}\text { Recruit- } \\
\text { ing }\end{array}$ & NCT03964233 & $\begin{array}{l}\text { Boehringer } \\
\text { Ingelheim }\end{array}$ & 2019 \\
\hline \multirow[t]{7}{*}{$\begin{array}{l}\text { HDM201 } \\
\text { (Siremadlin) }\end{array}$} & $\begin{array}{l}\text { Uveal mela- } \\
\text { ) noma }\end{array}$ & LXS196 & $\begin{array}{l}\text { PKC } \\
\text { inhibitor }\end{array}$ & I & $\begin{array}{l}\text { Recruit- } \\
\text { ing }\end{array}$ & NCT02601378 & $\begin{array}{l}\text { Novartis } \\
\text { Pharmaceu- } \\
\text { ticals }\end{array}$ & 2016 \\
\hline & $\begin{array}{l}\text { Advanced/ } \\
\text { metastatic } \\
\text { colorectal } \\
\text { cancer }\end{array}$ & Trametinib & $\begin{array}{l}\text { MEK } \\
\text { inhibitor }\end{array}$ & I & $\begin{array}{l}\text { Recruit- } \\
\text { ing }\end{array}$ & NCT03714958 & $\begin{array}{l}\text { Centre Leon } \\
\text { Berard }\end{array}$ & 2018 \\
\hline & $\begin{array}{l}\text { Myelofi- } \\
\text { brosis }\end{array}$ & Ruxolitinib & $\begin{array}{l}\text { TK inhibi- } \\
\text { tor }\end{array}$ & $|/| \mid$ & $\begin{array}{l}\text { Recruit- } \\
\text { ing }\end{array}$ & NCT04097821 & $\begin{array}{l}\text { Novartis } \\
\text { Pharmaceu- } \\
\text { ticals }\end{array}$ & 2019 \\
\hline & $\begin{array}{l}\text { Range of } \\
\text { cancers }\end{array}$ & Spartalizumab & $\begin{array}{l}\text { Anti- } \\
\text { PD-1 }\end{array}$ & I & $\begin{array}{l}\text { Recruit- } \\
\text { ing }\end{array}$ & NCT02890069 & $\begin{array}{l}\text { Novartis } \\
\text { Pharmaceu- } \\
\text { ticals }\end{array}$ & 2016 \\
\hline & $\begin{array}{l}\text { Malignant } \\
\text { solid } \\
\text { tumors }\end{array}$ & Ribociclib & $\begin{array}{l}\text { CDK } \\
\text { inhibitor }\end{array}$ & $\|$ & $\begin{array}{l}\text { Recruit- } \\
\text { ing }\end{array}$ & NCT04116541 & $\begin{array}{l}\text { Centre Leon } \\
\text { Berard }\end{array}$ & 2020 \\
\hline & $\begin{array}{l}\text { Acute mye- } \\
\text { logenous } \\
\text { leukemia }\end{array}$ & Midostaurin & $\begin{array}{l}\text { TK inhibi- } \\
\text { tor }\end{array}$ & । & $\begin{array}{l}\text { Recruit- } \\
\text { ing }\end{array}$ & NCT04496999 & $\begin{array}{l}\text { University } \\
\text { Hospital } \\
\text { Inselspital, } \\
\text { Berne }\end{array}$ & 2020 \\
\hline & $\begin{array}{l}\text { Acute mye- } \\
\text { logenous } \\
\text { leukemia, } \\
\text { myelod- } \\
\text { ysplastic } \\
\text { syndromes }\end{array}$ & $\begin{array}{l}\text { MBG453 } \\
\text { (Sabatolimab) } \\
\text { Venetoclax }\end{array}$ & $\begin{array}{l}\text { Anti- } \\
\text { Tim3 } \\
\text { BCL-2 } \\
\text { inhibitor }\end{array}$ & $\mathrm{lb}$ & $\begin{array}{l}\text { Recruit- } \\
\text { ing }\end{array}$ & NCT03940352 & $\begin{array}{l}\text { Novartis } \\
\text { Pharmaceu- } \\
\text { ticals }\end{array}$ & 2021 \\
\hline $\begin{array}{l}\text { DS-3032b } \\
\text { (Miladem- } \\
\text { etan) }\end{array}$ & $\begin{array}{l}\text { Acute mye- } \\
\text { logenous } \\
\text { leukemia, } \\
\text { relapsed } \\
\text { and refrac- } \\
\text { tory AML }\end{array}$ & $\begin{array}{l}\text { Cytarabine } \\
\text { Venetoclax }\end{array}$ & $\begin{array}{l}\text { DNA } \\
\text { damage } \\
\text { BCL-2 } \\
\text { inhibitor }\end{array}$ & $|/| \mid$ & $\begin{array}{l}\text { Recruit- } \\
\text { ing }\end{array}$ & NCT03634228 & $\begin{array}{l}\text { M.D. Ander- } \\
\text { son Cancer } \\
\text { Center }\end{array}$ & 2018 \\
\hline
\end{tabular}


Table 2 (continued)

\begin{tabular}{|c|c|c|c|c|c|c|c|c|}
\hline Drug & Disease & $\begin{array}{l}\text { Combination } \\
\text { with }\end{array}$ & & Phase & Status & Trial nr & Sponzor & $\begin{array}{l}\text { Start } \\
\text { date }\end{array}$ \\
\hline \multirow[t]{3}{*}{$\begin{array}{l}\text { ALRN- } \\
6924\end{array}$} & $\begin{array}{l}\text { Pediatric } \\
\text { cancer }\end{array}$ & Cytarabine & $\begin{array}{l}\text { DNA } \\
\text { damage }\end{array}$ & I & $\begin{array}{l}\text { Recruit- } \\
\text { ing }\end{array}$ & NCT03654716 & $\begin{array}{l}\text { Dana-Farber } \\
\text { Cancer } \\
\text { Institute }\end{array}$ & 2018 \\
\hline & $\begin{array}{l}\text { Small cell } \\
\text { lung cancer }\end{array}$ & Topotecan & & $|\mathrm{b} /| \mid$ & $\begin{array}{l}\text { Recruit- } \\
\text { ing }\end{array}$ & NCT04022876 & $\begin{array}{l}\text { Aileron } \\
\text { Therapeu- } \\
\text { tics }\end{array}$ & 2019 \\
\hline & $\begin{array}{l}\text { Breast can- } \\
\text { cer, malig- } \\
\text { nant solid } \\
\text { neoplasm }\end{array}$ & Paclitaxel & & $\mathrm{lb}$ & $\begin{array}{l}\text { Recruit- } \\
\text { ing }\end{array}$ & NCT03725436 & $\begin{array}{l}\text { M.D. Ander- } \\
\text { son Cancer } \\
\text { Center }\end{array}$ & 2019 \\
\hline
\end{tabular}

$T K$ tyrosine kinase, $P K C$ protein kinase $C$

advanced solid tumours or lymphomas with aberrant MDM2 signalling and wild-type p53 (NCT01877382) [66]. Patients are recruiting to one other study.

Another class of MDM2 inhibitors is cell penetrating stapled alpha-helical peptides designed to bind to both MDM2 and MDMX in nanomolar affinities to disrupt their interaction with p53. The most promising appear to be ATSP-7041 and its analogue ALRN-6924 (Aileron Therapeutics) [67, 68]. ALRN-6924 markedly improves survival in AML xenograft models [69]. Clinically, ALRN-6924 was evaluated as monotherapy and in combination with cytarabine in patients with haematologic neoplasms (NCT02909972) and has advanced into a phase I/II clinical study in patients with advanced solid tumours or lymphomas retaining wild-type p53 (NCT02264613). ALRN6924 was well tolerated and the most frequent adverse side-effects were gastrointestinal [68]. Three additional clinical trials of ALRN-692 are ongoing.

Additionally, other types of MDM2 inhibitors have been developed, including those that block its E3 ligase activity such as HLI98 [70], JNJ-26854165 [71], MEL23 and MEL24 [72], that block heterodimerisation between MDMX and MDM2 such as MMRi6 and its analogue MMRi64 [73], and that block the RNA-binding activity of MDM2 [74]. These have not entered clinical trials so far.

\section{Sensitivity to MDM2 inhibitors}

Although several approaches to inhibit MDM2 function have been and are being developed, as outlined above, our review concentrates particularly on the most intensively investigated class of such inhibitors, those that target the binding interface of MDM2 to p53, such as nutlin. Despite their apparent uniformity and simplicity of action, a broad spectrum of responses to such agents is documented, implying that the overall outcome of p53 activation after MDM2 inhibition is influenced by upstream and downstream p53 signalling pathways. Indeed, numerous factors have now been shown to influence the response to MDM2 inhibition, demonstrating the need to understand the complex mechanism(s) involved if these agents are to fulfil their clinical promise. Here, we discuss factors affecting MDM2 inhibition efficacy and their potential for patient stratification.

\section{p53-dependent determinants}

Generally, p53 status is the major determinant of response [36, 40, 75, 76]. The use of MDM2 inhibitors in cancer types with low p53 mutation frequencies, such as thyroid 
carcinoma, acute myeloid leukaemia (AML), melanoma and others (Fig. 2), gave hope for this approach to be widely used in cancer treatment. The first experiments demonstrated that MDM2 inhibitors cause cell cycle arrest and apoptosis in wild-type p53 cancer cells, whereas only transient cell cycle arrest and minimal accumulation of p53 with low cytotoxic effects were observed in normal cells in animal models [39, 77]. However, a wider panel of p53 wild-type cells indicated that the response to MDM2 inhibitors ranges from cell cycle arrest to apoptosis [40]. We analysed TP53 status in relation to nutlin-3a sensitivity in 947 cell lines using data from the Genomics of Drug Sensitivity in Cancer database (GDSC1) [78]. We divided cell lines into those with wild-type or mutant/null p53 using data from the IARC TP53 database (version R20, July 2019 [79]). Figure 3 shows the distribution of nutlin-3a $\mathrm{IC}_{50}$ values in

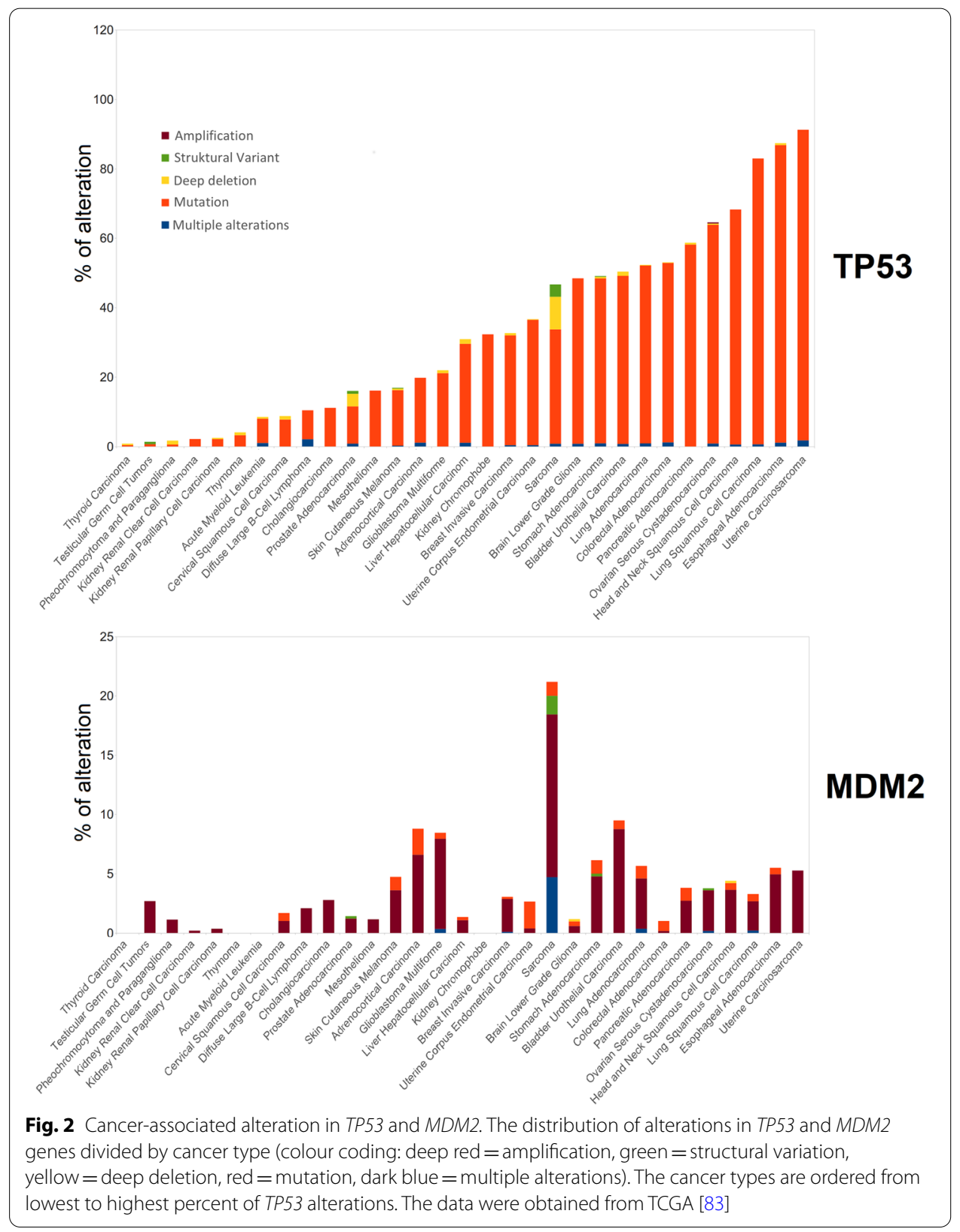


these two groups, with a clear dependence on TP53 status for most tissue subtypes. However, only around half of the tissue subtypes show statistical significance and the distribution of $\mathrm{IC}_{50}$ values is wide in some cases, seen for example for bladder, breast and osteosarcoma, indicating that criteria other than p53 mutation also influence nutlin-3a sensitivity. Moreover, we should consider TP53 mutations in a broader perspective, since not all TP53 mutations have the same impact on p53 inactivation [80]. For example, although many p53 mutations occur in the DNA binding domain and affect transactivation, other mutations impact protein-protein interactions [81]. Moreover, some mutations induce p53 gain of function, giving the tumour additional growth/survival advantages [82], and activating p53 in these cases may have an opposite effect.

\section{MDM2 status}

Apart from TP53 mutations, MDM2 overexpression is a common means by which the p53 pathway is inactivated. MDM2 gene amplification is found in various tumours, most notably sarcomas (Fig. 2), and tends to occur mutually exclusively with TP53 mutation. A single nucleotide polymorphism in the MDM2 promoter (SNP309) and deletion of the ARF-INK4a locus are other means for MDM2 overexpression [14, 84]. Thus, MDM2 inhibition is potentially promising especially for MDM2 amplified tumours with wildtype p53, and MDM2 protein level is a determinant of the response to MDM2 inhibitor treatment in vitro $[40,85,86]$. However, no correlation was observed between MDM2 amplification and effectiveness of response in AML [87]. Moreover, no correlation was observed between MDM2 and apoptotic outcome of nutlin-3 in sarcomas [88], and a

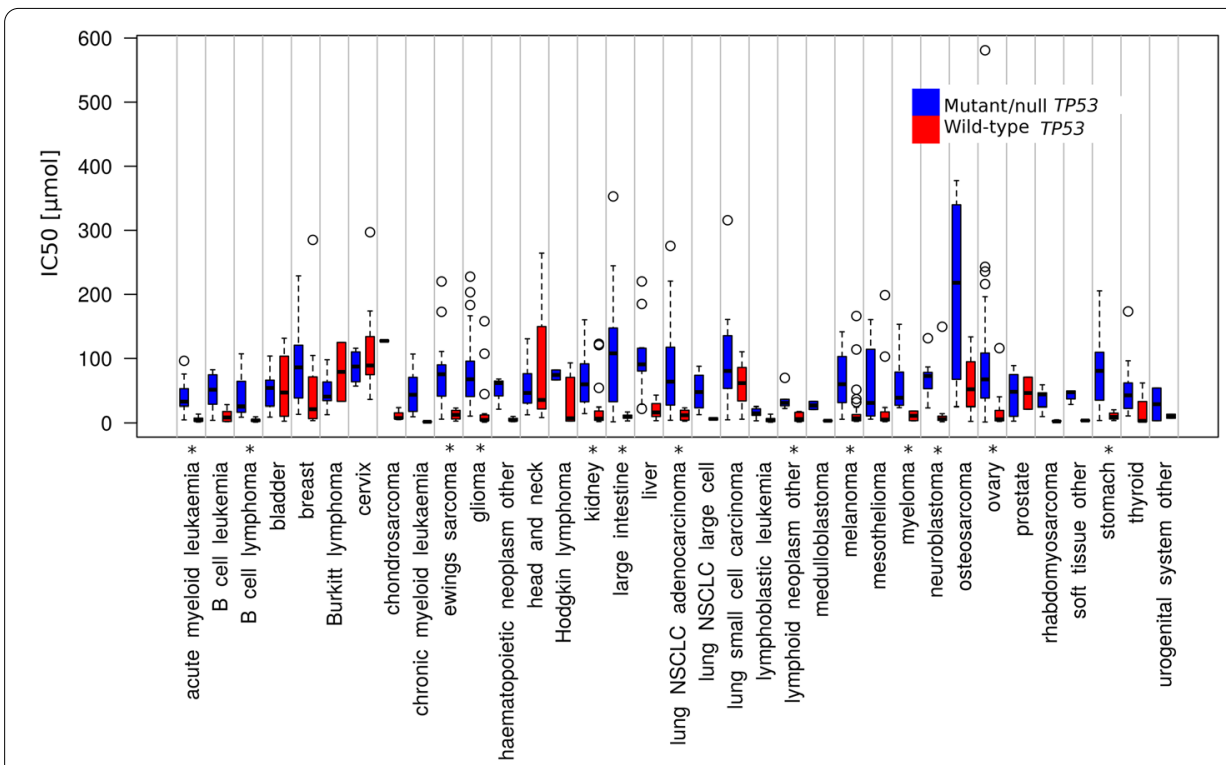

Fig. $3 \quad I_{50}$ values for nutlin-3a across cancer types. Box-plot of $I C_{50}$ values for human cancer cell lines divided by tissue subtype. Cell lines from each tissue subtypes are divided based on their TP53 status into wild type (red) and mutant/null (blue) groups. Differences in $\mathrm{IC}_{50}$ values between the two groups were evaluated by Mann-Whitney test; ${ }^{*} p<0.01$. Data were obtained from Genomics of Drug Sensitivity in Cancer (dataset GDSC1; GDSC; [78]), and the IARC TP53 database (version R20, July 2019; [79]) was used for distribution according to $p 53$ status 
clinical trial of patients with MDM2-amplified liposarcomas yielded a poor response to MDM2 inhibition as monotherapy [35], suggesting that MDM2 amplification is not a universal marker for therapy response. Again, the simplistic notions of using MDM2 inhibition in cancer therapy are not borne out in the clinic, despite evidence in their favour from in vitro models.

\section{MDMX status}

Indeed, several mechanisms interfering with MDM2 inhibition have been described. One of the first came from the MDM2 family member MDMX. Like MDM2, MDMX overexpression is common in several tumour types and represents an alternative mechanism of p53 inactivation [89-91]. Although MDMX and MDM2 share the same binding site on p53, there are differences in their binding mode [92], and several MDM2 inhibitors do not bind efficiently to MDMX [47, 93, 94]. However, MDMX forms a complex with MDM2 and enhances its ability to ubiquitinate p53, MDM2 and MDMX itself [95-97]. Consequently, the ratio between MDM2 and MDMX levels plays a critical role in p53 regulation [96]. The complexity of these interactions is underlined by evidence that MDM2 and MDMX binding can be enhanced by p53 and nutlin-3a [98]. Furthermore, nutlin-3a was ineffective in tumours overexpressing MDMX, and this resistance was reversed following deletion of the MDMX RING domain that is important for the interaction with MDM2 $[99,100]$. In line with this, a search for factors that interfere with MDM2 inhibition identified MDMX as one of the main drivers of resistance [101], and MDMX overexpression correlates with poor response to nutlin-3a in chronic lymphocytic leukaemia (CLL) cells [102] but not in AML cells [87]. Due to the involvement in MDM2 inhibition resistance and because MDMX is itself involved in cancer development, MDMX became a target of anti-tumour treatment and several MDMX or dual MDM2-MDMX inhibitors were developed (summarised in Types of MDM2 inhibitors).

\section{Cell cycle influences}

MDM2 inhibitors alter key molecules involved in cell cycle regulation via p53-dependent regulation or crosstalk, and these may also be involved in sensitivity (Fig. 4). $\mathbf{R b}$ (retinoblastoma protein) is a tumour suppressor involved in cell cycle progression that associates with E2F and represses its transcriptional activity [103]. When Rb is inactivated by phosphorylation by cyclin dependent kinase CDK2 or CDK4/6, it releases E2F for cell cycle progression [104-106]. MDM2 is responsible for proteasomal degradation of hypophosphorylated $\mathrm{Rb}[107,108]$ and promotes $\mathrm{Rb}$ translation in genotoxic conditions, resulting in G1 cell cycle arrest [109]. It was shown that Rb depletion by siRNA or inactivation via adenovirus E1A enhanced the nutlin-3-induced apoptotic response. This effect can be explained by activation of E2F transcriptional activity, with p73 induction in $\mathrm{Rb}$ mutant cells playing a critical role in apoptosis after nutlin-3 [110]. MDM2 upregulation by $\mathrm{p} 53$ activation after nutlin-3 reduced $\mathrm{Rb}$ phosphorylation and increased hypophosphorylated $\mathrm{Rb}$ in a panel of wild-type $\mathrm{p} 53$ cell lines, with the exception of nutlin-3 sensitive SJSA-1 cells harbouring MDM2 amplification, where downregulation of hypophosphorylated RB was observed [111]. This downregulation is p53-dependent and occurs through induction of the cyclin-dependent kinase inhibitor p21 (the major p53 target for inducing growth arrest, also known as $\mathrm{p} 21^{\text {cip1/waf1 }}$ or cyclin dependent kinase 


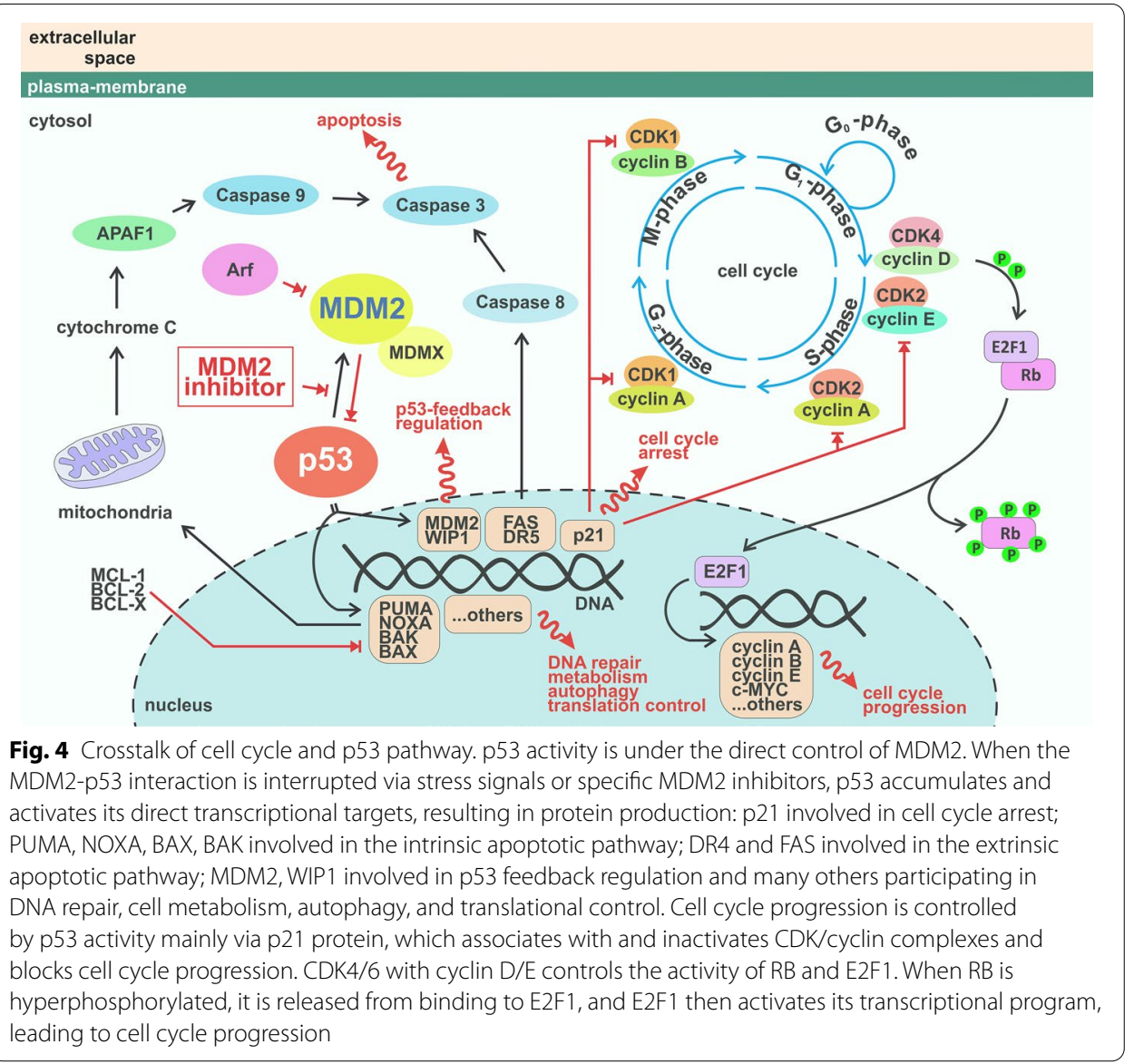

inhibitor 1A, CDKN1A), and seems to play a critical role in triggering apoptosis [111]. However, $M D M 2$ amplification in SJSA-1 cells cannot explain nutlin-induced Rb regulation in general, as it was not observed in other cell lines with $M D M 2$ amplification [111], nor is MDM2 amplification always present in nutlin-3 sensitive cells [110]. Nutlin-3 downregulation of RB was also observed in melanoma cell lines, and E2F1 levels dictate nutlin-3 sensitivity: sensitive melanoma cells accumulated MDM2, inducing p21 and lowering E2F1 levels, whereas resistant cells accumulated MDM2 but maintained E2F1 and showed less potent upregulation of p21 [112]. Rb is often mutated and E2F1 activity increased in tumour cells, making these aspects relevant considerations for MDM2 inhibition therapy.

Cyclins are important regulators of cell cycle progression, and their crosstalk with the p53 pathway is essential. As mentioned above, $\mathrm{Rb}$ phosphorylation is controlled by the cyclin D1-CDK4/CDK2 complex. Cyclin D1 is upregulated by nutlin-3, and cell lines became more sensitive by decreasing its level [113]. Cyclin D1 is commonly overexpressed in breast cancer and drives tumour growth by constitutive Rb hyperphosphorylation and E2F activation [114, 115]. In a model system of mammary cells transformed by cyclin D1/CDK activity, nutlin-3 was still able to cause p53 dependent growth arrest by repressing CDK1 and cyclin B1 [116]. 
Overexpression of MDM2 and CDK4 occurs in several tumour types such as liposarcoma, melanoma and osteosarcomas, and targeting both MDM2 and CDK4 is of interest in such settings, evidenced by a synergistic effect in liposarcomas [117]. This combination was subsequently evaluated in patients with locally advanced or metastatic liposarcoma (NCT02343172) (Table 1), demonstrating a manageable safety profile and favourable results compared to single-agent CDK4 inhibitor [64]. A phase II study aims to assess the efficacy and safety of this combination for patients with advanced/metastatic cancers based on their molecular alterations (NCT04116541). However, a recent study in sarcoma cell lines uncovered no synergistic effect of CDK4 and MDM2 inhibition and, on the contrary, CDK4 inhibition antagonised nutlin-3a and led to downregulation of p53 and its target genes [118]. The direct association of cyclin D1/CDK4 and p53/MDM2 seems responsible for this effect. CDK4 inhibition increased the occupancy of p53 on its target genes but diminished RNA polymerase II recruitment to these genes, resulting in decreased expression. Co-administration of MDM2 inhibitor was beneficial in melanoma cells resistant to CDK4/6 inhibition, characterised by abnormal PI3K/ AKT (phosphoinositide 3-kinase/protein kinase B) signalling, and CDK4/6 inhibition upregulated cyclin D1 that sequestered p21. The addition of MDM2 inhibition caused p21 upregulation by $\mathrm{p} 53$, leading to CDK2 inhibition and tumour regression in patientderived xenografts [119]. These examples illustrate the need to specifically define cellular backgrounds in which dual inhibition will be beneficial.

The involvement of cyclin B1/CDK1 and its substrate iASPP (inhibitor of apoptosis stimulating protein p53) was examined in a melanoma model. Compared to normal melanocytes, iASPP, MDM2 and cyclin B1 are often overexpressed in melanoma. iASPP phosphorylated by cyclin B1/CDK1 localises to the nucleus, binds p53 and inhibits p53-mediated transcription of apoptosis related genes PIG3, BAX and PUMA, but not the senescence related gene $C D K N 1 A$. High nuclear iASPP levels were associated with metastasis and poor patient survival. Inhibiting iASPP phosphorylation by cyclin B/CDK1 inhibition, or iASPP knockdown by siRNA, enhanced the apoptotic function of p53 after nutlin-3 treatment, representing a promising strategy for melanoma [120].

\section{PI3K/AKT, PTEN, mTOR and autophagy}

The PI3K/AKT pathway is important in promoting cell cycle progression and regulates the p53 response on multiple levels (upstream/downstream). PI3K phosphorylates and activates AKT, resulting in effects such as p21 stabilisation to aid survival [121] and MDM2 localisation to the nucleus to inhibit p53 [122]. The PI3K/AKT pathway is inhibited by PTEN (phosphatase and tensin homologue) [123-125], an important tumour suppressor [126]. Studies of acute lymphoblastic leukaemia (ALL) revealed that nutlin-3 upregulated p53 in all wild-type p53 cells, but apoptosis was induced only in PTEN-positive cells. Survivin (also called BIRC5, a member of the inhibitor of apoptosis family of proteins) is also an AKT-induced protein and its silencing sensitised cells to nutlin-3. Inhibition of PI3K/AKT signalling synergised with nutlin-3 to induce apoptosis in ALL [127]. Later, it was shown that survivin is regulated by p53-dependent upregulation of p21 upon nutlin-3 treatment [128]. In contrast, ERT fibroblasts expressing E1A, RAS and hTERT remain susceptible to nutlin-3 mediated apoptosis after PTEN or p73 loss 
[129]. These contradictory results from different systems raise questions about their relevance for the clinic.

PI3K/AKT signalling is crucial in regulating mTOR (mammalian target of rapamycin) activity, and mTOR was shown to play a role in the decision between cellular senescence and quiescence after nutlin-3a treatment in HT1080 and WI-38-tert cell lines [130, 131]. Inhibiting AKT/mTOR in AML (where mTOR signalling is often constitutively activated) impedes the transcriptional activation of p53 by nutlin-3. At the same time, nutlin-3 increased mitochondrial apoptosis by p53-mediated conformational change of BAX (BCL2 associated X protein) after dual AKT/mTOR and MDM2 inhibition [132]. Combined AKT/mTOR and MDM2 inhibition caused a synergistic antiproliferative effect and accelerated apoptosis in glioblastoma multiforme cells, a cancer type with high resistance to conventional chemotherapy [133]. Nutlin-3a treatment of mantle cell lymphoma, an aggressive type of B-cell non-Hodgkin lymphoma with cyclin D1 overexpression, decreased AKT phosphorylation at Ser473, causing p53-dependent AKT/mTOR pathway inhibition mediated by AMPK (AMP-activated protein kinase). Interestingly, nutlin-3a led to p53 Ser15 phosphorylation but AMPK inhibition did not affect p53 Ser15 phosphorylation, indicating that this pathway occurs in the order: p53 activation-AMPK activation-mTOR inhibition [134]. AMPK activation induced by nutlin-3a was also observed in AML and led to autophagy. The authors suggested that this autophagy induction promotes apoptosis, as autophagy blockade impaired nutlininduced apoptosis [135]. However, other studies suggest that autophagy acts against MDM2-inhibition-induced apoptosis and autophagy blockade can increase sensitivity for this treatment [136-138].

Autophagy is induced by glucose starvation and glucose levels correlate with nutlin3a sensitivity. Resistant cells are characterised by glycolysis and elevated levels of alphaketoglutarate, a TCA (tricarboxylic acid) cycle metabolite, and lower levels of OGDH (alpha-ketoglutarate dehydrogenase) compared to responsive cells. Targeting autophagy by glucose deprivation, treatment with 2-D-glucose or the autophagy inhibitor chloroquine or bafilomycin A1 enhanced the apoptotic response to nutlin-3a, suggesting that glycolysis-related autophagy is involved in MDM2 inhibitor resistance [137, 138]. Moreover, the p53-dependent activation of AKT and transcription factor SP1 due to nutlin-3a treatment is seen in wild-type p53 MDM2 non-amplified cells only, and leads to reduced glucose metabolism and resistance to apoptosis [139]. Autophagy blockade is indeed an effective way of restoring p53-induced apoptosis in nutlin-3a treated cells, as shown by the example of autophagy induced in an ATM (ataxia telangiectasia mutated)-dependent manner [136]. ATM signalling is a multifunctional pathway acting against tumour growth as well as promoting it in specific conditions [140]. ATM inhibits p53-dependent cell death after MDM2 inhibition, and cells in which ATM is depleted are susceptible to killing by nutlin-3 [141]. ATM inhibition did not change p53-dependent transcription but resulted in increased mitochondrial turnover and reactive oxygen species (ROS) production [136]. Importantly, nutlin-3a can activate ATM as part of the DNA damage response [142], which promotes p53 stabilisation by phosphorylation on Ser15. Initially, it was believed that nongenotoxic activation of p 53 does not lead to $\mathrm{p} 53$ phosphorylation [143], but several studies demonstrated that these phosphorylation events are present in various cell lines and settings and are important for p53 transcriptional function [134, 
142, 144]. Moreover, activated ATM phosphorylates MDM2 on Ser395, which switches MDM2 from a negative to a positive regulator of TP53 mRNA translation. However, in the absence of the TP53 mRNA-MDM2 interaction, Ser395 phospho-MDM2 has a greater capacity to ubiquitinate p53, leading to its degradation [145-147]. In addition, the interplay between MDM2-ATM-p53 and TP53 mRNA plays a significant role in p53 stabilisation [148]. Thus, it will be important to know how these functions of ATM are orchestrated in response to MDM2 inhibitors.

\section{FLT3 signalling}

In AML, a malignancy with low p53 mutation frequency, broad sensitivity of wildtype p53 cells to MDM2 inhibition was observed. Interestingly, mutation of $\boldsymbol{F L T 3}$, one of the most commonly mutated genes in AML leading to constitutive activation of its tyrosine kinase activity and subsequent activation of PI3K/RAS/STAT, correlates with low sensitivity to MDM2 inhibition and is a predictive marker of response [87]. Indeed, FLT3 inhibition and nutlin-3a exhibit synergy [149, 150], and there is a phase I clinical trial open for recruitment focussed on combination treatment for AML patients with mutated FLT3 and wild-type TP53 (NCT04496999) (Table 2).

\section{MAPK/ERK signalling}

Crosstalk between the p53 pathway and the MAPK/ERK (mitogen activated protein kinase/extracellular signal-regulated kinase) pathway plays an important role in MDM2 inhibitor response. Nutlin-3 induces phosphorylation of MEK1/2 (dual specificity mitogen-activated protein kinase kinase 1/2) and ERK1/2 in a p53-dependent manner but independent of p53-transcriptional activity. After nutlin-3 treatment, p53 translocates to mitochondria, leading to the generation of ROS and subsequent phosphorylation of ERK1/2 [151]. ERK1/2 signalling activates the transcription factor ELK1, resulting in increased expression of BCL2A1, an anti-apoptotic BCL2 (B-cell lymphoma-2) family protein [152]. Inhibition of ERK1/2, MEK1/2, ELK1 and BCL2A1 enhances the apoptotic response to nutlin-3, demonstrating the restrictive action of the ERK pathway on the nutlin-3 response [151, 152]. Inhibition of MAPK/ERK and MDM2 exhibits synergistic effects in AML that are dependent on upregulation of PUMA (p53 up-regulated modulator of apoptosis, alternatively BBC3) and BIM (BCL-2 interacting mediator of cell death, alternatively BCL2L11) [153]. The combination of the MDM2 inhibitor AMG232 and the MEK1/MEK2 inhibitor trametinib was evaluated in phase Ib clinical trials (NCT02016729, NCT02110355), showing good pharmacokinetic properties and antitumour activity $[50,51]$. There is one running phase I clinical study of combined MDM2 inhibitor and MEK inhibitor focused on RAS/RAF mutant and wild-type p53 colorectal carcinomas (NCT03714958).

\section{p53 transcriptional-dependent and independent effects}

Notwithstanding the above considerations, there is no doubt that p53 downstream signalling affects the outcome of MDM2 inhibition. The general feature of MDM2 inhibition in wild-type p53 cells is the p53-dependent upregulation of p21 leading to cell cycle arrest $[28,37,40,154]$. The p21 level was shown to have no decision effect on the apoptotic response to nutlin-3a in cancer cell lines [128] or in lymphoma cells in a mouse 
model [155]. However, p21 induction influences many response determinants, as mentioned previously for survivin, CDK4 and others $[119,128]$.

MDM2 inhibition also influences p53-transcription dependent regulation of genes of the intrinsic apoptotic pathway called the pro-apoptotic BH3-only members of the BCL-2 protein family, such as PUMA and NOXA (also called PMAIP1). The capacity of nutlin-3a to clear tumour cells is dependent on PUMA activation in a mouse model, and its loss partially protects lymphoma cells from nutlin-3a mediated killing [155]. p53 also regulates transcription of extrinsic apoptotic pathway genes such as FAS (also called CD95, TNFRSF6, or apoptosis antigen 1) [37, 155-157] or DR5 (also known as TRAILR2). The p53-dependent activation of the FAS death receptor pathway by nutlin3a plays a significant role in cell killing in cisplatin-resistant testicular carcinoma cells [158], whilst DR5 is important in breast cancer and melanoma cell lines [159, 160].

Several studies have focussed on identifying genes differentially expressed in cells sensitive to MDM2 inhibition. Differences in p53 target gene expression with and without nutlin-3 were evaluated in patient-derived B-CLL cells, showing that all wild-type p53 samples accumulated p53 after nutlin-3 treatment but only 13 out of 16 samples induced the same set of genes [161]. One study identified a 13-gene signature that predicted patient response [162], but re-evaluation in only wild-type p53 tumours revealed that this signature is not a good prediction tool [163]. Interestingly, p53 activated by DNA damage or nutlin-3a led to the same chromatin occupancy by p53 and similar chromatin changes, indicating that p53 uses the same transcriptional programme when activated by different stresses and the differences in cellular outcome are likely caused by other regulations [164]. Moreover, the same mRNA pattern was visible across cells with different sensitivity to nutlin-3, suggesting that regulation may be on the level of mRNA translation [141]. Indeed, the p53 response is regulated by post-transcriptional regulation by RNA-binding proteins and noncoding RNAs [165], and TP53 mRNA is tightly controlled by post-transcriptional regulation in stress conditions [166]. Rizzotto et al. investigated differences in polysome-bound mRNAs (those mRNAs undergoing translation) in SJSA-1 cells undergoing apoptosis and in HCT116 cells undergoing cell cycle arrest after nutlin-3a treatment. They identified a CG-rich motif (CGPD) in differentially expressed mRNAs, which is recognised by DHX30 (DExH-box helicase 30) and PCBP2 (Poly $(\mathrm{RC})$ binding protein 2). DHX30 expression in HCT116 cells reduced the translational efficiency of CGPD-containing mRNAs, and its depletion enhanced nutlin-3a-induced apoptosis [167].

There is an increasing body of evidence that p53 contributes to apoptosis via cytoplasmic accumulation, mitochondrial translocation and interaction with BCL-2 protein family members including BAX, BAK, BCL-2 and BCL-XL [168]. This transcriptionindependent role and the indispensability of direct interaction of p53 with mitochondrial antiapoptotic proteins for apoptosis induction after nutlin-3a treatment were reported in CLL cells $[36,169]$. Surprisingly, blocking p53 transcriptional activity enhanced the mitochondrial p53 death programme and increased the overall apoptotic outcome of nutlin-3a in leukaemia and colon carcinoma cells [170].

Bcl2l1 (BCL2-like 1) coding for BCL-XL was identified as the second most abundant factor causing resistance to the MDM2 inhibitor HDM201 in a mouse model. BCL-XL inhibition by a dual inhibitor of BCL-2/BCL-XL exerted synergistic effects in 35 of 135 
cell lines tested, indicating dependence on this resistance mechanism in some cellular backgrounds [101]. These results are consistent with an AML model, where combination MDM2 and BCL-2/X-L inhibition ameliorated tumour regression [171]. A phase Ib clinical study (NCT02670044) of combination MDM2 and BCL-2 inhibitors in relapsed or refractory AML demonstrated encouraging safety and efficacy in patients who were ineligible for cytotoxic chemotherapy [172].

The balance between apoptotic versus antiapoptotic gene activation by p53 is believed to be important in cell fate decisions [173]. The effect of key antiapoptotic regulators was evaluated in nutlin-3a apoptosis resistant HCT116 cells [174]. Depletion of MCL-1 (myeloid cell leukaemia sequence 1), cIAP1 (cellular inhibitor of apoptosis 1) or FLIP(L) (Fas-associated death domain [FADD]-like interleukin-1 $\beta$-converting enzyme inhibitory protein, isoform L) enhanced the response to nutlin-3a. FLIP(L) blocks caspase- 8 activity and can supress p53-mediated induction of PUMA, thus counteracting apoptosis induced by nutlin-3a [174]. MCL-1 is another antiapoptotic protein from the BCL-2 family that blocks apoptosis by binding BAX and BAK. MCL-1 is upregulated in melanoma cell lines by nutlin-3a, even in p53-mutant or -null cells [160].

NOTCH1, a known p53 target [175], is upregulated by nutlin-3a in wild-type p53 but not mutant or null leukaemic cell lines [176]. NOTCH1 upregulation protects against apoptosis and can restrain the efficacy of the treatment. Nutlin-3a abolished osteoclastogenic events, a drawback of NOTCH signalling inhibitors, making combined treatment a promising strategy for NOTCH-dependent tumours [176].

Another p53 target gene, WIP1 (Wild-type p53-induced phosphatase 1, also called protein phosphatase 1D), negatively regulates p53 activity. In stress conditions, WIP1 is upregulated by p53 and inhibits p53 activity by dephosphorylation of p53-Ser15 and of MDM2 and MDMX, thereby enabling cell cycle progression [177-179]. WIP1 overexpression is often found in breast cancer with wild-type p53, and dual targeting of WIP1 and MDM2 yielded synergistic effects [180]. WIP1 inhibition or depletion enhanced p53 target gene transcription in nutlin-3a treated cells, suggesting dependency of the nutlin3a response on WIP1 levels [181].

\section{Interactions with immune responses and the tumour microenvironment}

p53 also influences immune responses to protect against tumour growth [3], and studies concerning the impact of wild-type p53 activation by MDM2 inhibitors on the immune response and tumour microenvironments are now emerging. Activation of the p53 response by MDM2 inhibition potentiates dendritic cell maturation, increases the level of tumour infiltrating leukocytes and induces T-cell mediated killing of tumour cells. This p53-dependent immune activation is important for targeting tumour microenvironments characterised by immunosuppressive ability [182-184]. Nutlin-3a was also shown to be crucial in activating natural killer cells via p53-dependent upregulation of ligands for NKG2D (NK cell receptor D, also known as killer cell lectin-like receptor K1, KLRK1), a key recognition receptor for detecting and eliminating transformed and infected cells, and DNAM1 (DNAX accessory molecule-1; CD226) expressed on the surface of NK cells to mediate their cytotoxicity upon ligand binding [185]. Moreover, nutlin-3a induces the immune receptors PD-L1 (programmed death-ligand 1) and CD276 (cluster of differentiation 276, also called B7-H3) in distinct ways [186], increased CD276 
is p53-dependent and is mediated via MDM2-CD276 interaction, whereas increased PD-L1 is favoured in a p53-null phenotype or in settings where p53-MDM2 interaction is disrupted by MDM2 inhibition. Upregulation of PD-L1 and CD276 by MDM2 inhibition results in antagonistic effects of this treatment by diminishing T-cell killing of cancer cells. These findings demonstrate that MDM2 inhibition may contribute to immune evasion of cancer cells. However, the immune evasion is complex and includes many other regulatory mechanisms [187]. In addition, recent results indicate that MDM2 inhibitors may sensitise tumours to T-cell mediated killing in combination with antiPD-1 therapy, regardless of changes in PD-L1 expression [183, 188]. These reports of crosstalk between p53 and the immune response raise the following questions: What are the determinants of successful immune activation by p53 in the tumour microenvironment? And how can this be translated to improve patient-specific therapy? These questions are being addressed by clinical trials of combined MDM2 inhibitor and monoclonal antibodies targeting PD-1/PD-L1 that have started for breast cancer, advanced solid tumours, liposarcomas, metastatic melanomas, and colorectal and renal cell carcinomas (NCT03566485, NCT03611868, NCT04785196, NCT03964233, NCT02890069).

\section{p53-independent mechanisms of MDM2 inhibitors}

Besides its main role in p53 regulation, MDM2 is also involved in DNA repair [17, 18], DNA replication [189, 190], mitochondrial dynamics [191], angiogenesis [16, 22] and gene expression [192]. As described earlier, MDM2 inhibition is generally more effective in wild-type p53 cells than those harbouring TP53 mutations (Fig. 3). However, p53mutant or p53-null cell lines demonstrated that MDM2 inhibition impacts the cell in p53-independent but MDM2-dependent ways. Several p53-independent responses are documented, caused mainly by disruption of MDM2 binding to other proteins, or by offtarget activity of MDM2 inhibitors.

For the former, the $\mathrm{N}$-terminal domain of MDM2 represents an important interaction interface for many proteins such as p73, p63, DP1, HAUSP, hTERT, NUMB and NOTCH [193], and MDM2 inhibitors that bind to this domain potentially abolish these interactions. Moreover, MDM2 exhibits structural plasticity and allosteric changes impact its functions $[145,194]$, implying that not only $\mathrm{N}$-terminal interacting proteins are influenced by MDM2 inhibitors. One of the first pieces of evidence for a p53-independent action of nutlin-3 came from Ambrosini et al. in 2007. By comparing the effect of nutlin-3a on cell lines expressing wild-type p53, mutant p53 or lacking p53, they showed p53-independent E2F1 stabilisation, explained by inhibition of the interaction between MDM2 and E2F1. Nutlin-3a enhanced the cytotoxicity of genotoxic agents through E2F1 activation and subsequent transcription of proapoptotic p73 and NOXA [195].

The involvement of p73 in p53-independent nutlin-3a induced cell death has been examined in several studies. TAp73 $\alpha$, the longest isoform of p73 and which contains the p53-like transactivation domain, is a p53 family member able to transactivate p53-responsive genes. MDM2 binds to the N-terminal region of TAp73 via its hydrophobic pocket, resulting in suppression of TAp73 transcriptional activity [196]. Nutlin3a disrupts the interaction, leading to increased TAp73 transcriptional activity. Using siRNA against $\mathrm{p} 73$ or a dominant negative $\mathrm{p} 73$ form, the apoptotic effect of nutlin-3a in p53-mutant or p53-null cells was indeed shown to depend on p73 transcriptional 
activity. Moreover, possible activation via E2F1 was excluded [197]. Interestingly, nutlin-3a enhanced cytotoxicity in a doxorubicin resistant p53-mutant neuroblastoma cell line by activating both E2F1 and p73, showing its potential benefit for highly aggressive chemoresistant p53-null tumours [198].

The pro-angiogenic effect of MDM2 represents one of its oncogenic activities and is linked to the upregulation of VEGF (vascular endothelial growth factor) and HIF-1a (hypoxia inducible factor $1-\alpha$ ) in both normoxic and hypoxic conditions [199]. The crosstalk between p53 and HIF- $1 \alpha$ is complex and they can act either in parallel or in competition, depending on cell type, type of stress, etc. This complexity is underlined by independent MDM2 interactions with HIF- $1 \alpha$ protein and VEGF mRNA that influence VEGF expression [16, 199-201]. MDM2 inhibition has antiangiogenic activity through inhibiting HIF-1 $\alpha$ activation and blocking VEGF expression [202-204]. Mechanistically, HIF- $1 \alpha$ binds MDM2 and nutlin-3a inhibits this interaction. In p53-null cells, nutlin-3 is still able to functionally inactivate HIF- $1 \alpha$ by dissociating MDM2 binding to the HIF- $1 \alpha$ C-terminal transactivation domain to regulate hypoxic responses [205].

Application of an MDM2 antagonist will paradoxically lead to MDM2 upregulation due to the positive feedback loop between wild-type p53 and MDM2. This mechanism was suggested to cause partial resistance by reducing wild-type p53 activity. On the other hand, MDM2 degrades HIPK2 (homeodomain-interacting protein kinase 2) [206], a serine-threonine kinase responsible for phosphorylation of p53 at Ser46 to enhance apoptosis [207, 208]. Thus, nutlin-3 reduces HIPK2 by MDM2-mediated degradation, resulting in mitotic arrest instead of apoptosis, and differences in HIPK2 expression or functionality therefore contribute to sensitivity to MDM2 inhibition [206].

IGF-1R (insulin-like growth factor type 1 receptor) is another example of a protein regulated by nutlin-3 induced upregulation of MDM2, resulting in IGF-1R degradation [209]. IGF-1R is a known MDM2 substrate and is involved in many malignancies [210-213]. MDM2 targets IGF-1R for ubiquitination through amino acids 161-400 of MDM2, residues not occupied by nutlin-3 [214]. Intriguingly, nutlin-3a triggers IGF-1R activation, a process that is independent of p53 status but dependent on interaction with MDM2, thus fine-tuning ERK activation [209] and contributing to p53-dependent nutlin-3 induced ERK signalling [151]. Furthermore, cisplatin-resistant osteosarcoma cells characterised by elevated basal activation of IGF-1R/AKT display hypersensitivity to nutlin-3a but reduced AKT-dependent autophagy flux, and inhibiting IGF-1R, AKT or autophagy flux improved the nutlin-3a response [215].

MDM2 can localise to the cytosol and mitochondria, where it can affect oxidative respiration-related proteins [216]. Nutlin-3a perturbs mitochondrial protein-protein interactions, mediated by MDM2 interaction with DLD (dihydrolipoamide dehydrogenase), an enzyme involved in mitochondrial metabolism [217]. Recently, the involvement of MDM2 in ROS production and mitochondrial apoptosis was demonstrated and depends on interaction with NDFUS1 (NADH:ubiquinone oxidoreductase $75 \mathrm{kDa} F-\mathrm{F}$ protein 1) from the respiratory chain. Following nutlin-3a treatment, MDM2's effect on respiration is reinforced by increased association of MDM2 and NDFUS1 [218].

As MDM2 antagonists are designed to mimic p53 residues that are involved not only in MDMD2/MDMX binding but also in many other p53-protein interactions, this type of MDM2 antagonist exerts off-target activity. Off-target binding was documented for 
BCL- $\mathrm{X}_{\mathrm{L}}$, and BCL-2 and can contribute to $\mathrm{p} 53$-transcription independent mitochondrial apoptosis [219]. Another p53-independent effect of MDM2 inhibitors was explored on the level of DNA damage. MDM2 inhibition, often described as nongenotoxic, may trigger DNA damage responses in some circumstances, as documented by the formation of double-strand breaks, H2AX Ser139 phosphorylation and activation of ATM, Chk2 and BRCA1, and these events are p53-independent as they occur in p53-null cells [142, 220]. The activation of DNA damage responses was seen even after MDM2 depletion, suggesting that it is not related to MDM2 antagonism [142]. Although the mechanism responsible for MDM2-independent DNA damage by MDM2 inhibitors has not been identified, MDM2 and MDMX play roles in DNA break repair independently of p53 $[18,221]$. Interestingly, the nutlin-3a induced upregulation of MDM2 in wild-type p53 and p53-null cells inhibits DNA double strand break repair [222]. Thus, it is likely that MDM2 inhibitors trigger higher mutational levels in cells.

In addition, MDM2 inhibition in p53-null or p53-mutant cells enhances the effects of other cancer treatments such as DNA damaging agents [198, 223], arsenic trioxide [224], or bortezomib [225]. Having mentioned the potential benefits of MDM2 inhibition in p53-null or -mutant cells, these are not the target group in clinical trials, which instead focus on wild-type p53 tumours.

\section{Acquired resistance to MDM2 inhibition}

Acquired resistance constitutes one of the main obstacles for advanced and metastatic tumours. Tumours may respond well to treatment initially, but there is emergence of adapted non-responding cells by activation of oncogenes, inactivating mutations in tumour suppressors, change of the tumour microenvironment affecting drug absorption and immunosurveillance, and many other factors [226, 227]. It was thought that MDM2 inhibitors as a type of nongenotoxic target therapy would suffer less with problems of acquired resistance compared to conventional chemotherapy [228]. Unfortunately, acquired resistance represents a particular problem for MDM2 inhibitors, as even short treatment results in generation of resistant cell populations across divergent cell lines [229-231]. Resistance originating from activation of ABC transporters such as P-glycoprotein leading to efflux of chemotherapeutic agents [232] is instrumental in resistance to nutlin-3a in colorectal cancer cells [233].

The leading cause of acquired resistance of MDM2 inhibitors is attributed to the acquisition of new mutations. Adapted cells are characterised by acquiring loss of function mutations in TP53, mainly in its sequence coding the DNA binding domain [229, 234, 235]. Moreover, these resistant cells emerge by de novo mutations and are resistant not only to additional MDM2 inhibitor application but also to a broad spectrum of chemotherapies [234, 235]. Interestingly, the frequency of TP53 gene mutations is much higher after MDM2 inhibition than after cytotoxic agents, indicating selection pressure for TP53 mutated cells and suggesting that p53-independent functions of MDM2 are involved in this selection process $[234,236]$.

Although TP53 mutations after prolonged MDM2 inhibition are the most frequent, other regulatory pathways are also altered and are a likely cause of acquired multidrug resistance. Whole genome sequencing and transcriptome analysis of resistant cells revealed that N-RAS (neuroblastoma RAS viral oncogene homologue), MAPK/ERK, 
IGFBP1 (insulin-like growth factor-binding protein 1) and NF- $\mathrm{kB}$ (nuclear factor- $\mathrm{kB}$ ) are upregulated [234, 237]. Activation of these pathways would explain the emergence of resistance to cell death, but further investigation will be needed to gain a deeper understanding of the molecular processes. In a recent study, Deben et al. [238] found that resistant cells derived from non-small cell lung cancer have increased gene expression of factors that promote epithelial-mesenchymal transition. The level of the transcription factor LEF-1 (lymphoid enhancer-binding factor 1), which induces gene expression of N-cadherin, vimentin and Snail, was significantly increased in nutlin-resistant cells. Other factors upregulated in resistant clones were matrix metalloproteinases involved in tumour invasion, neoangiogenesis-related and inflammation-related proteins such as CSF1-2, IL-5, IL-13, PD-L1, PD-L2, CD73, galectin-3 and CXCL1-3 [238]. Production of these inflammatory molecules and checkpoints influences the tumour microenvironment, increases tumour cell survival and thus contributes to chemoresistance [239]. Altogether, adapted cells are characterised by loss of p53 activity due to p53 inactivating mutation, increased proliferative and invasive activity, or changes in the tumour microenvironment. Acquired resistance will compromise the effect of other chemotherapeutics that use p53 activation for clearance of tumour cells [203], or other target therapies such as MEK inhibitors [240]. Hence, it is likely that the order and combination of therapeutic approaches will be an important consideration.

The development of new MDM2 inhibitors upgraded characteristics including affinity for MDM2, cell permeability and toxicity. Nevertheless, the generation of resistant cells seems to be universal for MDM2 inhibitors as documented for RG7388 [237], MI-63 [241], HDM201 [101], idasanutlin [235] and SAR405838 [242] in both in vitro and in vivo systems. Moreover, using SAR405838, the development of secondary resistance does not depend on whether a fixed drug concentration is applied or the drug concentration is gradually increased over time [242].

Initial results from a clinical trial confirm that MDM2 inhibitor leads to a higher proportion of TP53 mutant subclones by selection of a pre-existing cell sub-population. Interestingly, these mutant subclones decrease after treatment cessation [243]. It is not known yet whether these TP53 mutations will compromise the effect of the treatment. Thus, monitoring adapted cells within tumour heterogeneity will be an important step in placing acquired resistance in the context of patient treatment.

\section{Conclusions and perspectives}

In cancer cells bearing wild-type p53, MDM2 inhibitors brought satisfactory results regarding p53 activation. Unfortunately, the overall outcome of this activation varies greatly due to multiple factors that influence p53 pathway activation or p53-independent MDM2 functions (Fig. 5). Moreover, MDM2 inhibitor response is influenced differently by the same genetic alteration in different systems, and predicting patient response is further complicated by intratumoural heterogeneity, influence of the immune system, nutrition, etc. Efforts to find universal predictive biomarkers for MDM2 inhibition will likely fail due to this diversity. However, improved understanding of the specific pathway(s) responsible for resistance in an individual patient will aid the prediction of their specific biomarker-a panel of markers rather than a single marker will need to be assessed for optimal use of MDM2 inhibitors in personalised medicine. As an exemplar, 


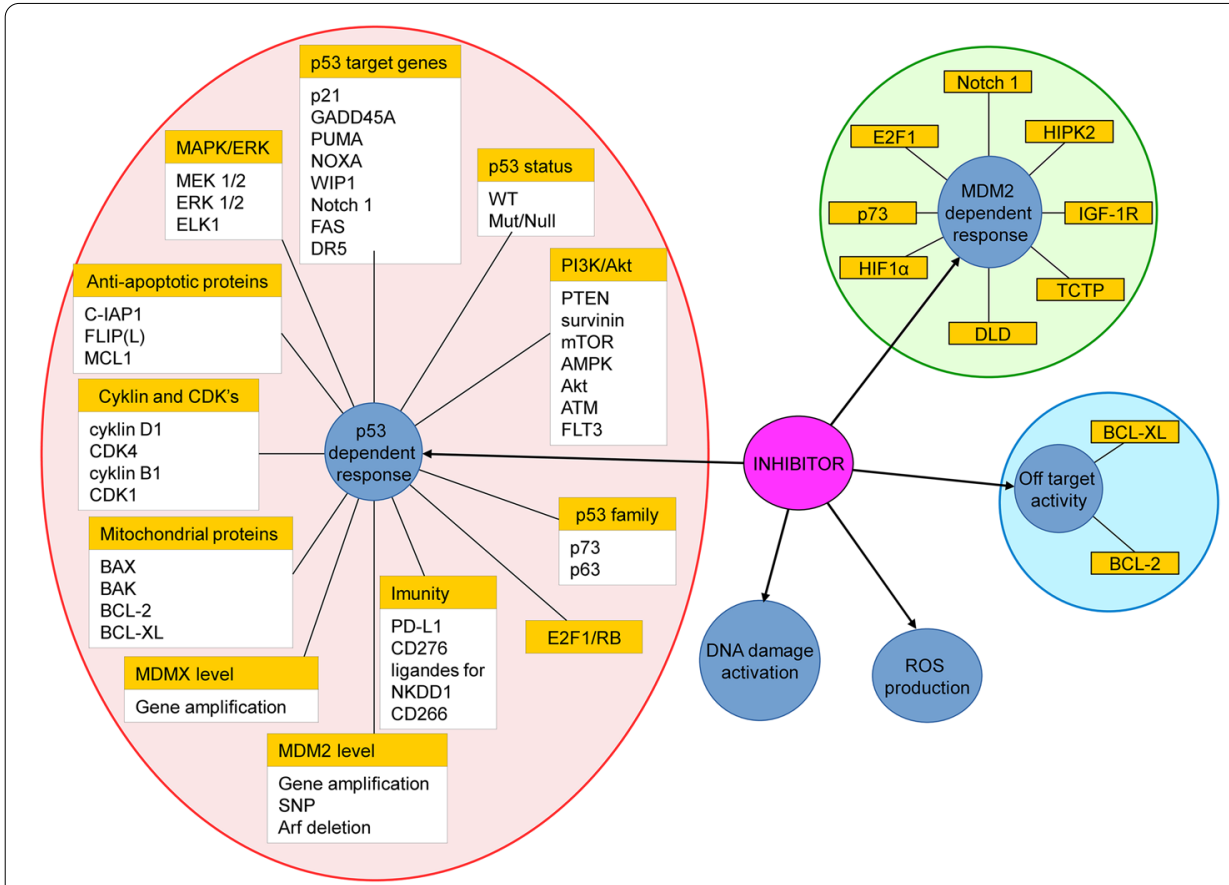

Fig. 5 Determinants of response to MDM2 inhibitors. The overall representation of factors determining sensitivity to MDM2 inhibitors divided into MDM2-dependent determinants, p53-dependent determinants, off-targets and other determinants. The determinants are divided into related groups of proteins. All of these factors were reported in the literature to affect the sensitivity to MDM2 inhibitors designed to disrupt the p53-MDM2 interaction interface

AML commonly has wild-type p53 but has low sensitivity to MDM2 inhibitors due to FLT3 mutation [87]. Preclinical studies showed that dual inhibition of MDM2 and FLT3 improves outcome for those patients $[87,149,150]$ and a clinical trial (NCT04496999) is underway based on those findings. Similarly, whilst all of the determinants of MDM2 inhibitor responses mentioned in this review are worth further study, we do not expect that they will all play a significant role, and re-evaluation of these factors is required to identify their value for predicting response and informing treatment decisions, including the best combination therapy for the individual tumour. Unfortunately, promotion of mutant p53 subclones occurs after MDM2 inhibition, although cessation of MDM2 inhibitor leads to their regression [243]. That higher single doses of MDM2 inhibitors are more effective for activating a p53 apoptotic response [41] indicates that dose and duration of MDM2 inhibition should be reconsidered to reduce acquired resistance. Finally, results from ongoing or planned clinical trials that assess MDM2 inhibitors together with tumour-specific targeting drugs should provide useful information for identifying predictive biomarkers and for designing appropriate combination therapies in the era of personalised medicine. Although not yet a complete success, the future of MDM2 inhibitors is bright.

Abbreviations

AKT: Protein kinase B; ALL: Acute lymphoblastic leukaemia; AML: Acute myeloid leukaemia; AMPK: AMP-activated protein kinase; ATM: Ataxia telangiectasia mutated; BAX: BCL2 associated X protein; BCL2: B-cell lymphoma-2; BIM: BCL-2 interacting mediator of cell death; CDK: Cyclin dependent kinase; CD276: Cluster of differentiation 276; CIAP1: Cellular inhibitor 
of apoptosis 1; CLL: Chronic lymphocytic leukaemia; CYP3A4: Cytochrome P450 3A4; DHX30: DExH-box helicase 30; DLD: Dihydrolipoamide dehydrogenase; DNAM1: DNAX accessory molecule-1; ERK: Extracellular signal-regulated kinase; FLIP(L): Fas-associated death domain [FADD]-like interleukin-1 $\beta$-converting enzyme inhibitory protein, isoform L; FLT3ITD: Fms related receptor tyrosine kinase 3 internal tandem duplication; GDSC: Genomics of drug sensitivity in cancer database; HIF-1 a: Hypoxia inducible factor 1-a; HIPK2: Homeodomain-interacting protein kinase 2; iASPP: Inhibitor of apoptosis stimulating protein p53; IGFBP1: Insulin-like growth factor-binding protein 1; IGF-1 R: Insulin-like growth factor type 1 receptor; LEF-1: Lymphoid enhancer-binding factor 1; MAPK: Mitogen activated protein kinase; MCL-1: Myeloid cell leukaemia sequence 1; MEK1/2: Dual specificity mitogen-activated protein kinase 1/2; mTOR: Mammalian target of rapamycin; NDFUS1: NADH:ubiquinone oxidoreductase 75 kDa Fe-S protein 1; NKG2D: NK cell receptor D; N-RAS: Neuroblastoma RAS viral oncogene homologue; NF-kB: Nuclear factor-kB; OGDH: Alpha-ketoglutarate dehydrogenase; PCBP2: Poly(RC) binding protein 2; PD-L1: Programmed death-ligand 1; PI3K: Phosphoinositide 3-kinase; PTEN: Phosphatase and tensin homologue; PUMA: P53 up-regulated modulator of apoptosis; RB: Retinoblastoma protein; ROS: Reactive oxygen species; TCA: Tricarboxylic acid cycle; VEGF: Vascular endothelial growth factor; WIP1: Wild-type p53-induced phosphatase 1.

\section{Acknowledgements}

We apologize to those whose works have not been cited in this article owing to lack of space. This article was specially invited by the editors and represents work by leading researchers

\section{Authors' contributions}

$\mathrm{LH}, \mathrm{OB}, \mathrm{PZ}$ and MK collected the literature, and designed and wrote the manuscript. LH, BV, PJC and RF edited and prepared the manuscript for submission. FK-Z analysed statistical data and contributed to graphics. All authors read and approved the final manuscript.

\section{Funding}

This work was supported by a Czech Science Foundation project (No. 19-18177Y), by the European Regional Development Fund_Project ENOCH (No. CZ.02.1.01/0.0/0.0/16_019/0000868), by the Ministry of Health Development of Research Organization, MH CZ - DRO (MMCl, 00209805) and by Cancerforskningsfonden Norr as well as Cancerfonden (No. 1900073). Ondrej Bonczek was supported by scholarship from the Wenner-Gren Foundations in Sweden.

\section{Availability of data and materials}

The datasets analysed during the current study are available in the GDSC repository, [https://www.cancerrxgene.org/ compound/Nutlin-3a\%20(-)/1047/by-tissue?], accessed 10 March, 2021.

\section{Declarations}

Ethics approval and consent to participate

Not applicable.

\section{Consent for publication}

Not applicable.

\section{Competing interests}

The authors declare that they have no competing interests.

\section{Author details}

${ }^{1}$ RECAMO, Masaryk Memorial Cancer Institute, Zluty kopec 7, 65653 Brno, Czech Republic. ${ }^{2}$ Department of Medical Biosciences, Umea University, 90187 Umea, Vasterbotten, Sweden. ${ }^{3}$ National Centre for Biomolecular Research, Faculty of Science, Masaryk University, Kamenice 5, 62500 Brno, Czech Republic. ${ }^{4}$ Inserm UMRS1131, Institut de Génétique Moléculaire, Université Paris 7, Hôpital St. Louis, 75010 Paris, France.

Received: 4 August 2021 Accepted: 5 November 2021

Published online: 15 December 2021

\section{References}

1. Ho T, Tan BX, Lane D. How the other half lives: what p53 does when it is not being a transcription factor. Int J Mol Sci. 2019;21(1):13

2. Marchenko ND, Moll UM. Mitochondrial death functions of p53. Mol Cell Oncol. 2014;1(2):e955995.

3. Blagih J, Buck MD, Vousden KH. p53, cancer and the immune response. J Cell Sci. 2020. https://doi.org/10.1242/jcs. 237453.

4. Haupt Y, Maya R, Kazaz A, Oren M. Mdm2 promotes the rapid degradation of p53. Nature. 1997;387(6630):296-9.

5. Honda R, Tanaka H, Yasuda H. Oncoprotein MDM2 is a ubiquitin ligase E3 for tumor suppressor p53. FEBS Lett. 1997:420(1):25-7.

6. Lane DP, Midgley CA, Hupp TR, Lu X, Vojtesek B, Picksley SM. On the regulation of the p53 tumour suppressor, and its role in the cellular response to DNA damage. Philos Trans R Soc Lond B. 1995;347(1319):83-7.

7. Barak Y, Juven T, Haffner R, Oren M. mdm2 expression is induced by wild type p53 activity. EMBO J. 1993;12(2):461-8.

8. Wu X, Bayle JH, Olson D, Levine AJ. The p53-mdm-2 autoregulatory feedback loop. Genes Dev. 1993;7(7A):1126-32 
9. Jones $\mathrm{SN}$, Roe AE, Donehower LA, Bradley A. Rescue of embryonic lethality in Mdm2-deficient mice by absence of p53. Nature. 1995;378(6553):206-8.

10. Montes de Oca Luna R, Wagner DS, Lozano G. Rescue of early embryonic lethality in mdm2-deficient mice by deletion of p53. Nature. 1995;378(6553):203-6.

11. Wasylishen AR, Lozano G. Attenuating the p53 pathway in human cancers: many means to the same end. Cold Spring Harb Perspect Med. 2016;6(8):a026211.

12. Herrero AB, Rojas EA, Misiewicz-Krzeminska I, Krzeminski P, Gutierrez NC. Molecular mechanisms of p53 deregulation in cancer: an overview in multiple myeloma. Int J Mol Sci. 2016;17(12):2003.

13. Oliner JD, Saiki AY, Caenepeel S. The role of MDM2 amplification and overexpression in tumorigenesis. Cold Spring Harb Perspect Med. 2016;6(6):a026336.

14. Bond GL, Hu W, Bond EE, Robins H, Lutzker SG, Arva NC, et al. A single nucleotide polymorphism in the MDM2 promoter attenuates the p53 tumor suppressor pathway and accelerates tumor formation in humans. Cell. 2004;119(5):591-602.

15. Oliner JD, Kinzler KW, Meltzer PS, George DL, Vogelstein B. Amplification of a gene encoding a p53-associated protein in human sarcomas. Nature. 1992;358(6381):80-3.

16. Muthumani P, Alagarsamy K, Dhandayuthapani S, Venkatesan T, Rathinavelu A. Pro-angiogenic effects of MDM2 through HIF-1alpha and NF-kappaB mediated mechanisms in LNCaP prostate cancer cells. Mol Biol Rep. 2014;41(8):5533-41.

17. Alt JR, Bouska A, Fernandez MR, Cerny RL, Xiao H, Eischen CM. Mdm2 binds to Nbs1 at sites of DNA damage and regulates double strand break repair. J Biol Chem. 2005;280(19):18771-81.

18. Bouska A, Lushnikova T, Plaza S, Eischen CM. Mdm2 promotes genetic instability and transformation independent of p53. Mol Cell Biol. 2008;28(15):4862-74.

19. Yang JY, Zong CS, Xia W, Wei Y, Ali-Seyed M, Li Z, et al. MDM2 promotes cell motility and invasiveness by regulating E-cadherin degradation. Mol Cell Biol. 2006;26(19):7269-82.

20. Yang JY, Zong CS, Xia W, Yamaguchi H, Ding Q, Xie X, et al. ERK promotes tumorigenesis by inhibiting FOXO3a via MDM2-mediated degradation. Nat Cell Biol. 2008;10(2):138-48.

21. Miwa S, Uchida C, Kitagawa K, Hattori T, Oda T, Sugimura H, et al. Mdm2-mediated pRB downregulation is involved in carcinogenesis in a p53-independent manner. Biochem Biophys Res Commun. 2006;340(1):54-61.

22. Wolf ER, Mabry AR, Damania B, Mayo LD. Mdm2-mediated neddylation of pVHL blocks the induction of antiangiogenic factors. Oncogene. 2020;39(29):5228-39.

23. Hou H, Sun D, Zhang X. The role of MDM2 amplification and overexpression in therapeutic resistance of malignant tumors. Cancer Cell Int. 2019;19:216.

24. Kussie PH, Gorina S, Marechal V, Elenbaas B, Moreau J, Levine AJ, et al. Structure of the MDM2 oncoprotein bound to the p53 tumor suppressor transactivation domain. Science. 1996;274(5289):948-53.

25. Grigoreva TA, Novikova DS, Petukhov AV, Gureev MA, Garabadzhiu AV, Melino G, et al. Proapoptotic modification of substituted isoindolinones as MDM2-p53 inhibitors. Bioorg Med Chem Lett. 2017;27(23):5197-202.

26. Gureev M, Novikova D, Grigoreva T, Vorona S, Garabadzhiu A, Tribulovich V. Simulation of MDM2 N-terminal domain conformational lability in the presence of imidazoline based inhibitors of MDM2-p53 protein-protein interaction. J Comput Aided Mol Des. 2020;34(1):55-70.

27. Neochoritis CG, Atmaj J, Twarda-Clapa A, Surmiak E, Skalniak L, Kohler LM, et al. Hitting on the move: targeting intrinsically disordered protein states of the MDM2-p53 interaction. Eur J Med Chem. 2019;182:111588.

28. Vassilev LT, Vu BT, Graves B, Carvajal D, Podlaski F, Filipovic Z, et al. In vivo activation of the p53 pathway by smallmolecule antagonists of MDM2. Science. 2004;303(5659):844-8.

29. Estrada-Ortiz N, Neochoritis CG, Domling A. How to design a successful p53-MDM2/X interaction inhibitor: a thorough overview based on crystal structures. ChemMedChem. 2016;11(8):757-72.

30. Bueren-Calabuig JA, Michel J. Elucidation of ligand-dependent modulation of disorder-order transitions in the oncoprotein MDM2. PLoS Comput Biol. 2015;11(6):e1004282.

31. Bista M, Wolf S, Khoury K, Kowalska K, Huang Y, Wrona E, et al. Transient protein states in designing inhibitors of the MDM2-p53 interaction. Structure. 2013;21(12):2143-51.

32. Uhrinova $\mathrm{S}$, Uhrin $\mathrm{D}$, Powers $\mathrm{H}$, Watt $\mathrm{K}$, Zheleva $\mathrm{D}$, Fischer $\mathrm{P}$, et al. Structure of free MDM2 N-terminal domain reveals conformational adjustments that accompany p53-binding. J Mol Biol. 2005;350(3):587-98.

33. Hernychova L, Man P, Verma C, Nicholson J, Sharma CA, Ruckova E, et al. Identification of a second Nutlin-3 responsive interaction site in the $\mathrm{N}$-terminal domain of MDM2 using hydrogen/deuterium exchange mass spectrometry. Proteomics. 2013;13(16):2512-25.

34. Xia M, Knezevic D, Tovar C, Huang B, Heimbrook DC, Vassilev LT. Elevated MDM2 boosts the apoptotic activity of p53-MDM2 binding inhibitors by facilitating MDMX degradation. Cell Cycle. 2008;7(11):1604-12.

35. Ray-Coquard I, Blay JY, Italiano A, Le Cesne A, Penel N, Zhi J, et al. Effect of the MDM2 antagonist RG7112 on the P53 pathway in patients with MDM2-amplified, well-differentiated or dedifferentiated liposarcoma: an exploratory proof-of-mechanism study. Lancet Oncol. 2012;13(11):1133-40.

36. Kojima K, Konopleva M, McQueen T, O'Brien S, Plunkett W, Andreeff M. Mdm2 inhibitor Nutlin-3a induces p53-mediated apoptosis by transcription-dependent and transcription-independent mechanisms and may overcome Atm-mediated resistance to fludarabine in chronic lymphocytic leukemia. Blood. 2006;108(3):993-1000

37. Drakos E, Thomaides A, Medeiros LJ, Li J, Leventaki V, Konopleva M, et al. Inhibition of p53-murine double minute 2 interaction by nutlin-3A stabilizes p53 and induces cell cycle arrest and apoptosis in Hodgkin lymphoma. Clin Cancer Res. 2007;13(11):3380-7.

38. Wasylyk C, Salvi R, Argentini M, Dureuil C, Delumeau I, Abecassis J, et al. p53 mediated death of cells overexpressing MDM2 by an inhibitor of MDM2 interaction with p53. Oncogene. 1999;18(11):1921-34.

39. Efeyan A, Ortega-Molina A, Velasco-Miguel S, Herranz D, Vassilev LT, Serrano M. Induction of p53-dependent senescence by the MDM2 antagonist nutlin-3a in mouse cells of fibroblast origin. Cancer Res. 2007;67(15):7350-7.

40. Tovar C, Rosinski J, Filipovic Z, Higgins B, Kolinsky K, Hilton H, et al. Small-molecule MDM2 antagonists reveal aberrant p53 signaling in cancer: implications for therapy. Proc Natl Acad Sci USA. 2006;103(6):1888-93. 
41. Jeay S, Ferretti S, Holzer P, Fuchs J, Chapeau EA, Wartmann M, et al. Dose and schedule determine distinct molecular mechanisms underlying the efficacy of the p53-MDM2 inhibitor HDM201. Cancer Res. 2018;78(21):6257-67.

42. Kim S, Chen J, Cheng T, Gindulyte A, He J, He S, et al. PubChem in 2021: new data content and improved web interfaces. Nucleic Acids Res. 2021;49(D1):D1388-95.

43. Vu B, Wovkulich P, Pizzolato G, Lovey A, Ding Q, Jiang N, et al. Discovery of RG7112: a small-molecule MDM2 inhibitor in clinical development. ACS Med Chem Lett. 2013;4(5):466-9.

44. Andreeff M, Kelly KR, Yee K, Assouline S, Strair R, Popplewell L, et al. Results of the phase I trial of RG7112, a smallmolecule MDM2 antagonist in leukemia. Clin Cancer Res. 2016;22(4):868-76.

45. Ding Q, Zhang Z, Liu JJ, Jiang N, Zhang J, Ross TM, et al. Discovery of RG7388, a potent and selective p53-MDM2 inhibitor in clinical development. J Med Chem. 2013;56(14):5979-83.

46. Reis B, Jukofsky L, Chen G, Martinelli G, Zhong H, So WV, et al. Acute myeloid leukemia patients'clinical response to idasanutlin (RG7388) is associated with pre-treatment MDM2 protein expression in leukemic blasts. Haematologica. 2016;101(5):e185-8.

47. Rew Y, Sun D. Discovery of a small molecule MDM2 inhibitor (AMG 232) for treating cancer. J Med Chem. 2014;57(15):6332-41.

48. Sun D, Li Z, Rew Y, Gribble M, Bartberger MD, Beck HP, et al. Discovery of AMG 232, a potent, selective, and orally bioavailable MDM2-p53 inhibitor in clinical development. J Med Chem. 2014;57(4):1454-72.

49. Gluck WL, Gounder MM, Frank R, Eskens F, Blay JY, Cassier PA, et al. Phase 1 study of the MDM2 inhibitor AMG 232 in patients with advanced P53 wild-type solid tumors or multiple myeloma. Invest New Drugs. 2020;38(3):831-43.

50. Erba HP, Becker PS, Shami PJ, Grunwald MR, Flesher DL, Zhu M, et al. Phase $1 \mathrm{~b}$ study of the MDM2 inhibitor AMG 232 with or without trametinib in relapsed/refractory acute myeloid leukemia. Blood Adv. 2019;3(13):1939-49.

51. Moschos SJ, Sandhu SK, Lewis KD, Sullivan RJ, Johnson DB, Zhang Y, Rasmussen E, Henary HA, Long GL. Phase 1 study of the p53-MDM2 inhibitor AMG 232 combined with trametinib plus dabrafenib or trametinib in patients (Pts) with TP53 wild type (TP53WT) metastatic cutaneous melanoma (MCM). J Clin Oncol. 2017;35:2575.

52. Zhao Y, Yu S, Sun W, Liu L, Lu J, McEachern D, et al. A potent small-molecule inhibitor of the MDM2-p53 interaction (MI-888) achieved complete and durable tumor regression in mice. J Med Chem. 2013;56(13):5553-61.

53. Aguilar A, Lu J, Liu L, Du D, Bernard D, McEachern D, et al. Discovery of 4-((3'R, $\left.4^{\prime} S, 5^{\prime} R\right)-6^{\prime \prime}$-chloro-4'-(3-chloro-2fluorophenyl)-1'-ethyl-2"'-oxodispiro[cyclohexane-1,2'-pyrrolidine-3', 3"-indoline]-5'-carboxamido)bicyclo[2.2.2] octane-1-carboxylic acid (AA-115/APG-115): a potent and orally active murine double minute 2 (MDM2) inhibitor in clinical development. J Med Chem. 2017;60(7):2819-39.

54. Rasco DW, Lakhani NJ, Li Y, Men L, Wang H, Ji J, et al. A phase I study of a novel MDM2 antagonist APG-115 in patients with advanced solid tumors. J Clin Oncol. 2019;37(15_suppl):3126.

55. Tolcher AW, Reeves JA, McKean M, Chmielowski B, Beck JT, Shaheen MF, et al. Preliminary results of a phase II study of alrizomadlin (APG-115), a novel, small-molecule MDM2 inhibitor, in combination with pembrolizumab in patients (pts) with unresectable or metastatic melanoma or advanced solid tumors that have failed immunooncologic (I-O) drugs. J Clin Oncol. 2021;39(15_suppl):2506.

56. Rinnenthal J, Rudolph D, Blake S, Gollner A, Wernitznig A, Weyer-Czernilofsky U, et al. Abstract 4865: BI 907828: a highly potent MDM2 inhibitor with low human dose estimation, designed for high-dose intermittent schedules in the clinic. Cancer Res. 2018;78(13 Supplement):4865.

57. Cornillie J, Wozniak A, Li H, Gebreyohannes YK, Wellens J, Hompes D, et al. Anti-tumor activity of the MDM2-TP53 inhibitor BI-907828 in dedifferentiated liposarcoma patient-derived xenograft models harboring MDM2 amplification. Clin Transl Oncol. 2020;22(4):546-54.

58. Holzer P, Masuya K, Furet P, Kallen J, Valat-Stachyra T, Ferretti S, et al. Discovery of a dihydroisoquinolinone derivative (NVP-CGM097): a highly potent and selective MDM2 inhibitor undergoing phase 1 clinical trials in p53wt tumors. J Med Chem. 2015;58(16):6348-58.

59. Gessier F, Kallen J, Jacoby E, Chene P, Stachyra-Valat T, Ruetz S, et al. Discovery of dihydroisoquinolinone derivatives as novel inhibitors of the p53-MDM2 interaction with a distinct binding mode. Bioorg Med Chem Lett. 2015;25(17):3621-5.

60. Bauer S, Demetri GD, Halilovic E, Dummer R, Meille C, Tan DSW, et al. Pharmacokinetic-pharmacodynamic guided optimisation of dose and schedule of CGM097, an HDM2 inhibitor, in preclinical and clinical studies. Br J Cancer. 2021. https://doi.org/10.1038/s41416-021-01444-4.

61. Holzer P. Discovery of potent and selective P53-MDM2 protein-protein interaction inhibitors as anticancer drugs. Chimia (Aarau). 2017;71(10):716-21.

62. Seipel K, Marques MAT, Sidler C, Mueller BU, Pabst T. MDM2- and FLT3-inhibitors in the treatment of FLT3ITD acute myeloid leukemia, specificity and efficacy of NVP-HDM201 and midostaurin. Haematologica. 2018;103(11):1862-72.

63. Stein E, Chromik J, DeAngelo DJ, Chatterjee M, Noppeney R, Vos Fd, et al. Abstract CT152: phase I dose- and regimen-finding study of NVP-HDM201 in pts with advanced TP53 wt acute leukemias. Cancer Res. 2017;77(13 Supplement):CT152-CT.

64. Razak AA, Bauer S, Blay JY, Quek R, Suárez C, Lin CC, Hütter-Krönke ML, Cubedo R, Ferretti S, Meille C, Halilovic E, Clementi G, Santos-Rosa M, Guerreiro N, Jullion A, Fabre C, Italiano A. Results of a dose- and regimen-finding phase Ib study of HDM201 in combination with ribociclib in patients with locally advanced or metastatic liposarcoma. Cancer Res. 2018. https://doi.org/10.1158/1538-7445.AM2018-CT009.

65. Arnhold V, Schmelz K, Proba J, Winkler A, Wunschel J, Toedling J, et al. Reactivating TP53 signaling by the novel MDM2 inhibitor DS-3032b as a therapeutic option for high-risk neuroblastoma. Oncotarget. 2018;9(2):2304-19.

66. Bauer TM, Gounder MM, Weise AM, Schwartz GK, Carvajal RD, Kumar P, et al. A phase 1 study of MDM2 inhibitor DS-3032b in patients with well/de-differentiated liposarcoma (WD/DD LPS), solid tumors (ST) and lymphomas (L). J Clin Oncol. 2018;36(15_suppl):11514.

67. Chang YS, Graves B, Guerlavais V, Tovar C, Packman K, To KH, et al. Stapled alpha-helical peptide drug development: a potent dual inhibitor of MDM2 and MDMX for p53-dependent cancer therapy. Proc Natl Acad Sci USA. 2013;110(36):E3445-54. 
68. Meric-Bernstam F, Saleh MN, Infante JR, Goel S, Falchook GS, Shapiro G, et al. Phase I trial of a novel stapled peptide ALRN-6924 disrupting MDMX-and MDM2-mediated inhibition of WT p53 in patients with solid tumors and lymphomas. J Clin Oncol. 2017;35(15_suppl):2505.

69. Carvajal LA, Neriah DB, Senecal A, Benard L, Thiruthuvanathan V, Yatsenko T, et al. Dual inhibition of MDMX and MDM2 as a therapeutic strategy in leukemia. Sci Transl Med. 2018;10(436):eaao3003.

70. Yang Y, Ludwig RL, Jensen JP, Pierre SA, Medaglia MV, Davydov IV, et al. Small molecule inhibitors of HDM2 ubiquitin ligase activity stabilize and activate p53 in cells. Cancer Cell. 2005;7(6):547-59.

71. You L, Liu H, Huang J, Xie W, Wei J, Ye X, et al. The novel anticancer agent JNJ-26854165 is active in chronic myeloid leukemic cells with unmutated BCR/ABL and T315I mutant BCR/ABL through promoting proteosomal degradation of BCR/ABL proteins. Oncotarget. 2017;8(5):7777-90.

72. Herman AG, Hayano M, Poyurovsky MV, Shimada K, Skouta R, Prives C, et al. Discovery of Mdm2-MdmX E3 ligase inhibitors using a cell-based ubiquitination assay. Cancer Discov. 2011;1(4):312-25.

73. Wu W, Xu C, Ling X, Fan C, Buckley BP, Chernov MV, et al. Targeting RING domains of Mdm2-MdmX E3 complex activates apoptotic arm of the p53 pathway in leukemia/lymphoma cells. Cell Death Dis. 2015;6:e2035.

74. Gu L, Zhang H, Liu T, Zhou S, Du Y, Xiong J, et al. Discovery of dual inhibitors of MDM2 and XIAP for cancer treatment. Cancer Cell. 2016;30(4):623-36.

75. Hasegawa H, Yamada Y, Iha H, Tsukasaki K, Nagai K, Atogami S, et al. Activation of p53 by Nutlin-3a, an antagonist of MDM2, induces apoptosis and cellular senescence in adult T-cell leukemia cells. Leukemia. 2009;23(11):2090-101.

76. Bixby D, Kujawski L, Wang S, Malek SN. The pre-clinical development of MDM2 inhibitors in chronic lymphocytic leukemia uncovers a central role for p53 status in sensitivity to MDM2 inhibitor-mediated apoptosis. Cell Cycle. 2008;7(8):971-9.

77. Shangary S, Qin D, McEachern D, Liu M, Miller RS, Qiu S, et al. Temporal activation of p53 by a specific MDM2 inhibitor is selectively toxic to tumors and leads to complete tumor growth inhibition. Proc Natl Acad Sci USA. 2008;105(10):3933-8.

78. Yang W, Soares J, Greninger P, Edelman EJ, Lightfoot H, Forbes S, et al. Genomics of Drug Sensitivity in Cancer (GDSC): a resource for therapeutic biomarker discovery in cancer cells. Nucleic Acids Res. 2013;41(Database issue):D955-61.

79. Bouaoun L, Sonkin D, Ardin M, Hollstein M, Byrnes G, Zavadil J, et al. TP53 variations in human cancers: new lessons from the IARC TP53 database and genomics data. Hum Mutat. 2016;37(9):865-76.

80. Salomao N, Karakostis K, Hupp T, Vollrath F, Vojtesek B, Fahraeus R. What do we need to know and understand about p53 to improve its clinical value? J Pathol. 2021;254(4):443-53.

81. Walerych D, Lisek K, Sommaggio R, Piazza S, Ciani Y, Dalla E, et al. Proteasome machinery is instrumental in a common gain-of-function program of the p53 missense mutants in cancer. Nat Cell Biol. 2016;18(8):897-909.

82. Sabapathy K, Lane DP. Therapeutic targeting of $\mathrm{p} 53$ : all mutants are equal, but some mutants are more equal than others. Nat Rev Clin Oncol. 2018;15(1):13-30.

83. Weinstein JN, Collisson EA, Mills GB, Shaw KR, Ozenberger BA, Ellrott K, et al. The cancer genome atlas pan-cancer analysis project. Nat Genet. 2013;45(10):1113-20.

84. Zhang Y, Xiong Y, Yarbrough WG. ARF promotes MDM2 degradation and stabilizes p53: ARF-INK4a locus deletion impairs both the $\mathrm{Rb}$ and $\mathrm{p53}$ tumor suppression pathways. Cell. 1998;92(6):725-34.

85. Muller CR, Paulsen EB, Noordhuis P, Pedeutour F, Saeter G, Myklebost O. Potential for treatment of liposarcomas with the MDM2 antagonist Nutlin-3A. Int J Cancer. 2007;121(1):199-205.

86. Seyfried I, Hofbauer S, Stoecher M, Greil R, Tinhofer I. SNP309 as predictor for sensitivity of CLL cells to the MDM2 inhibitor nutlin-3a. Blood. 2008;112(5):2168; author reply 9.

87. Long J, Parkin B, Ouillette P, Bixby D, Shedden K, Erba H, et al. Multiple distinct molecular mechanisms influence sensitivity and resistance to MDM2 inhibitors in adult acute myelogenous leukemia. Blood. 2010;116(1):71-80.

88. Pishas KI, Neuhaus SJ, Clayer MT, Schreiber AW, Lawrence DM, Perugini M, et al. Nutlin-3a efficacy in sarcoma predicted by transcriptomic and epigenetic profiling. Cancer Res. 2014;74(3):921-31.

89. Riemenschneider MJ, Buschges R, Wolter M, Reifenberger J, Bostrom J, Kraus JA, et al. Amplification and overexpression of the MDM4 (MDMX) gene from 1932 in a subset of malignant gliomas without TP53 mutation or MDM2 amplification. Cancer Res. 1999;59(24):6091-6.

90. Ramos YF, Stad R, Attema J, Peltenburg LT, van der Eb AJ, Jochemsen AG. Aberrant expression of HDMX proteins in tumor cells correlates with wild-type p53. Cancer Res. 2001;61(5):1839-42.

91. Laurie NA, Donovan SL, Shih CS, Zhang J, Mills N, Fuller C, et al. Inactivation of the p53 pathway in retinoblastoma. Nature. 2006:444(7115):61-6.

92. Popowicz GM, Czarna A, HolakTA. Structure of the human Mdmx protein bound to the p53 tumor suppressor transactivation domain. Cell Cycle. 2008;7(15):2441-3.

93. Joseph TL, Madhumalar A, Brown CJ, Lane DP, Verma CS. Differential binding of p53 and nutlin to MDM2 and MDMX: computational studies. Cell Cycle. 2010;9(6):1167-81.

94. ElSawy KM, Verma CS, Joseph TL, Lane DP, Twarock R, Caves LS. On the interaction mechanisms of a p53 peptide and nutlin with the MDM2 and MDMX proteins: a Brownian dynamics study. Cell Cycle. 2013;12(3):394-404.

95. Linares LK, Hengstermann A, Ciechanover A, Muller S, Scheffner M. HdmX stimulates Hdm2-mediated ubiquitination and degradation of p53. Proc Natl Acad Sci USA. 2003;100(21):12009-14.

96. Gu J, Kawai H, Nie L, Kitao H, Wiederschain D, Jochemsen AG, et al. Mutual dependence of MDM2 and MDMX in their functional inactivation of p53. J Biol Chem. 2002;277(22):19251-4.

97. Pan Y, Chen J. MDM2 promotes ubiquitination and degradation of MDMX. Mol Cell Biol. 2003:23(15):5113-21.

98. Medina-Medina I, Martinez-Sanchez M, Hernandez-Monge J, Fahraeus R, Muller P, Olivares-Illana V. p53 promotes its own polyubiquitination by enhancing the HDM2 and HDMX interaction. Protein Sci. 2018;27(5):976-86.

99. Hu B, Gilkes DM, Farooqi B, Sebti SM, Chen J. MDMX overexpression prevents p53 activation by the MDM2 inhibitor Nutlin. J Biol Chem. 2006:281(44):33030-5. 
100. Patton JT, Mayo LD, Singhi AD, Gudkov AV, Stark GR, Jackson MW. Levels of HdmX expression dictate the sensitivity of normal and transformed cells to Nutlin-3. Cancer Res. 2006;66(6):3169-76.

101. Chapeau EA, Gembarska A, Durand EY, Mandon E, Estadieu C, Romanet V, et al. Resistance mechanisms to TP53MDM2 inhibition identified by in vivo piggyBac transposon mutagenesis screen in an Arf(-/-) mouse model. Proc Natl Acad Sci USA. 2017;114(12):3151-6.

102. Bo MD, Secchiero P, Degan M, Marconi D, Bomben R, Pozzato G, et al. MDM4 (MDMX) is overexpressed in chronic lymphocytic leukaemia (CLL) and marks a subset of p53wild-type CLL with a poor cytotoxic response to Nutlin-3. Br J Haematol. 2010;150(2):237-9.

103. Weintraub SJ, Prater CA, Dean DC. Retinoblastoma protein switches the E2F site from positive to negative element. Nature. 1992;358(6383):259-61.

104. Kato J, Matsushime H, Hiebert SW, Ewen ME, Sherr CJ. Direct binding of cyclin D to the retinoblastoma gene product (pRb) and pRb phosphorylation by the cyclin D-dependent kinase CDK4. Genes Dev. 1993;7(3):331-42.

105. Connell-Crowley L, Harper JW, Goodrich DW. Cyclin D1/Cdk4 regulates retinoblastoma protein-mediated cell cycle arrest by site-specific phosphorylation. Mol Biol Cell. 1997;8(2):287-301.

106. Wang QM, Luo X, Kheir A, Coffman FD, Studzinski GP. Retinoblastoma protein-overexpressing HL60 cells resistant to 1,25-dihydroxyvitamin D3 display increased CDK2 and CDK6 activity and shortened G1 phase. Oncogene. 1998;16(21):2729-37.

107. Sdek $\mathrm{P}$, Ying $\mathrm{H}$, Zheng $\mathrm{H}$, Margulis $\mathrm{A}$, Tang $\mathrm{X}$, Tian $\mathrm{K}$, et al. The central acidic domain of MDM2 is critical in inhibition of retinoblastoma-mediated suppression of E2F and cell growth. J Biol Chem. 2004;279(51):53317-22.

108. Sdek P, Ying H, Chang DL, Qiu W, Zheng H, Touitou R, et al. MDM2 promotes proteasome-dependent ubiquitinindependent degradation of retinoblastoma protein. Mol Cell. 2005;20(5):699-708.

109. Hernandez-Monge J, Martinez-Sanchez M, Rousset-Roman A, Medina-Medina I, Olivares-IIlana V. MDM2 regulates RB levels during genotoxic stress. EMBO Rep. 2021;22(1):e50615.

110. Kitagawa M, Aonuma M, Lee SH, Fukutake S, McCormick F. E2F-1 transcriptional activity is a critical determinant of Mdm2 antagonist-induced apoptosis in human tumor cell lines. Oncogene. 2008;27(40):5303-14.

111. Du W, Wu J, Walsh EM, Zhang Y, Chen CY, Xiao ZX. Nutlin-3 affects expression and function of retinoblastoma protein: role of retinoblastoma protein in cellular response to nutlin-3. J Biol Chem. 2009;284(39):26315-21.

112. Verhaegen $M$, Checinska A, Riblett MB, Wang S, Soengas MS. E2F1-dependent oncogenic addiction of melanoma cells to MDM2. Oncogene. 2012;31(7):828-41.

113. Yang $P$, Chen W, Li X, Eilers G, He Q, Liu L, et al. Downregulation of cyclin D1 sensitizes cancer cells to MDM2 antagonist Nutlin-3. Oncotarget. 2016;7(22):32652-63.

114. Baldin V, Lukas J, Marcote MJ, Pagano M, Draetta G. Cyclin D1 is a nuclear protein required for cell cycle progression in G1. Genes Dev. 1993;7(5):812-21.

115. Roy PG, Thompson AM. Cyclin D1 and breast cancer. Breast. 2006;15(6):718-27.

116. Kan CE, Patton JT, Stark GR, Jackson MW. p53-mediated growth suppression in response to Nutlin-3 in cyclin D1 transformed cells occurs independently of p21. Cancer Res. 2007;67(20):9862-8.

117. Laroche-Clary A, Chaire V, Algeo MP, Derieppe MA, Loarer FL, Italiano A. Combined targeting of MDM2 and CDK4 is synergistic in dedifferentiated liposarcomas. J Hematol Oncol. 2017;10(1):123.

118. Sriraman A, Dickmanns A, Najafova Z, Johnsen SA, Dobbelstein M. CDK4 inhibition diminishes p53 activation by MDM2 antagonists. Cell Death Dis. 2018;9(9):918.

119. Vilgelm AE, Saleh N, Shattuck-Brandt R, Riemenschneider K, Slesur L, Chen SC, et al. MDM2 antagonists overcome intrinsic resistance to CDK4/6 inhibition by inducing p21. Sci Transl Med. 2019;11(505):eaav7171.

120. Lu M, Breyssens H, Salter V, Zhong S, Hu Y, Baer C, et al. Restoring p53 function in human melanoma cells by inhibiting MDM2 and cyclin B1/CDK1-phosphorylated nuclear iASPP. Cancer Cell. 2013;23(5):618-33.

121. Li Y, Dowbenko D, Lasky LA. AKT/PKB phosphorylation of p21 Cip/WAF1 enhances protein stability of p21Cip/ WAF1 and promotes cell survival. J Biol Chem. 2002;277(13):11352-61.

122. Mayo LD, Donner DB. A phosphatidylinositol 3-kinase/Akt pathway promotes translocation of $\mathrm{Mdm} 2$ from the cytoplasm to the nucleus. Proc Natl Acad Sci USA. 2001;98(20):11598-603.

123. Li J, Simpson L, Takahashi M, Miliaresis C, Myers MP, Tonks N, et al. The PTEN/MMAC1 tumor suppressor induces cell death that is rescued by the AKT/protein kinase B oncogene. Cancer Res. 1998;58(24):5667-72.

124. Maehama T, Dixon JE. The tumor suppressor, PTEN/MMAC1, dephosphorylates the lipid second messenger, phosphatidylinositol 3,4,5-trisphosphate. J Biol Chem. 1998;273(22):13375-8.

125. Myers MP, Pass I, Batty IH, Van der Kaay J, Stolarov JP, Hemmings BA, et al. The lipid phosphatase activity of PTEN is critical for its tumor supressor function. Proc Natl Acad Sci USA. 1998;95(23):13513-8.

126. Chang H, Cai Z, Roberts TM. The mechanisms underlying PTEN loss in human tumors suggest potential therapeutic opportunities. Biomolecules. 2019;9(11):713.

127. Zhu N, Gu L, Li F, Zhou M. Inhibition of the Akt/survivin pathway synergizes the antileukemia effect of nutlin-3 in acute lymphoblastic leukemia cells. Mol Cancer Ther. 2008;7(5):1101-9.

128. Xia M, Knezevic D, Vassilev LT. p21 does not protect cancer cells from apoptosis induced by nongenotoxic p53 activation. Oncogene. 2011;30(3):346-55

129. Cipriano R, Patton JT, Mayo LD, Jackson MW. Inactivation of $\mathrm{p} 53$ signaling by $\mathrm{p} 73$ or PTEN ablation results in a transformed phenotype that remains susceptible to Nutlin-3 mediated apoptosis. Cell Cycle. 2010;9(7):1373-9.

130. Korotchkina LG, Demidenko ZN, Gudkov AV, Blagosklonny MV. Cellular quiescence caused by the Mdm2 inhibitor nutlin-3A. Cell Cycle. 2009;8(22):3777-81.

131. Korotchkina LG, Leontieva OV, Bukreeva El, Demidenko ZN, Gudkov AV, Blagosklonny MV. The choice between p53-induced senescence and quiescence is determined in part by the mTOR pathway. Aging (Albany NY) 2010;2(6):344-52.

132. Kojima K, Shimanuki M, Shikami M, Samudio IJ, Ruvolo V, Corn P, et al. The dual PI3 kinase/mTOR inhibitor PI-103 prevents $\mathrm{p} 53$ induction by Mdm2 inhibition but enhances p53-mediated mitochondrial apoptosis in p53 wildtype AML. Leukemia. 2008;22(9):1728-36. 
133. Daniele S, Costa B, Zappelli E, Da Pozzo E, Sestito S, Nesi G, et al. Combined inhibition of AKT/mTOR and MDM2 enhances Glioblastoma Multiforme cell apoptosis and differentiation of cancer stem cells. Sci Rep. 2015;5:9956.

134. Drakos E, Atsaves V, Li J, Leventaki V, Andreeff M, Medeiros LJ, et al. Stabilization and activation of p53 downregulates mTOR signaling through AMPK in mantle cell lymphoma. Leukemia. 2009;23(4):784-90.

135. Borthakur G, Duvvuri S, Ruvolo V, Tripathi DN, Piya S, Burks J, et al. MDM2 inhibitor, Nutlin 3a, induces p53 dependent autophagy in acute leukemia by AMP kinase activation. PLOS ONE. 2015;10(10):e0139254.

136. Sullivan KD, Palaniappan W, Espinosa JM. ATM regulates cell fate choice upon $\mathrm{p} 53$ activation by modulating mitochondrial turnover and ROS levels. Cell Cycle. 2015;14(1):56-63.

137. Duan L, Perez RE, Maki CG. Alpha ketoglutarate levels, regulated by p53 and OGDH, determine autophagy and cell fate/apoptosis in response to Nutlin-3a. Cancer Biol Ther. 2019;20(3):252-60.

138. Duan L, Perez RE, Davaadelger B, Dedkova EN, Blatter LA, Maki CG. p53-regulated autophagy is controlled by glycolysis and determines cell fate. Oncotarget. 2015;6(27):23135-56.

139. Duan L, Perez RE, Chen L, Blatter LA, Maki CG. p53 promotes AKT and SP1-dependent metabolism through the pentose phosphate pathway that inhibits apoptosis in response to Nutlin-3a. J Mol Cell Biol. 2018;10(4):331-40.

140. Cremona CA, Behrens A. ATM signalling and cancer. Oncogene. 2014;33(26):3351-60.

141. Sullivan KD, Padilla-Just N, Henry RE, Porter CC, Kim J, Tentler JJ, et al. ATM and MET kinases are synthetic lethal with nongenotoxic activation of p53. Nat Chem Biol. 2012;8(7):646-54.

142. Valentine JM, Kumar S, Moumen A. A p53-independent role for the MDM2 antagonist Nutlin-3 in DNA damage response initiation. BMC Cancer. 2011;11:79.

143. Thompson T, Tovar C, Yang H, Carvajal D, Vu BT, Xu Q, et al. Phosphorylation of $\mathrm{p} 53$ on key serines is dispensable for transcriptional activation and apoptosis. J Biol Chem. 2004;279(51):53015-22.

144. Loughery J, Cox M, Smith LM, Meek DW. Critical role for p53-serine 15 phosphorylation in stimulating transactivation at p53-responsive promoters. Nucleic Acids Res. 2014;42(12):7666-80.

145. Uhrik L, Wang L, Haronikova L, Medina-Medina I, Rebolloso-Gomez Y, Chen S, et al. Allosteric changes in HDM2 by the ATM phosphomimetic S395D mutation: implications on HDM2 function. Biochem J. 2019;476(21):3401-11.

146. Medina-Medina I, Garcia-Beltran P, de la Mora-de la Mora I, Oria-Hernandez J, Millot G, Fahraeus R, et al. Allosteric interactions by p53 mRNA govern HDM2 E3 ubiquitin ligase specificity under different conditions. Mol Cell Biol. 2016;36(16):2195-205

147. Gajjar M, Candeias MM, Malbert-Colas L, Mazars A, Fujita J, Olivares-Illana V, et al. The p53 mRNA-Mdm2 interaction controls Mdm2 nuclear trafficking and is required for p53 activation following DNA damage. Cancer Cell. 2012;21(1):25-35.

148. Karakostis K, Vadivel Gnanasundram S, Lopez I, Thermou A, Wang L, Nylander K, et al. A single synonymous mutation determines the phosphorylation and stability of the nascent protein. J Mol Cell Biol. 2019;11(3):187-99.

149. Zauli G, Celeghini C, Melloni E, Voltan R, Ongari M, Tiribelli M, et al. The sorafenib plus nutlin-3 combination promotes synergistic cytotoxicity in acute myeloid leukemic cells irrespectively of FLT3 and p53 status. Haematologica. [Research Support, Non-U.S. Gov't]. 2012;97(11):1722-30.

150. Seipel K, Marques MAT, Sidler C, Mueller BU, Pabst T. The cellular p53 inhibitor MDM2 and the growth factor receptor FLT3 as biomarkers for treatment responses to the MDM2-inhibitor idasanutlin and the MEK1 inhibitor cobimetinib in acute myeloid leukemia. Cancers (Basel). 2018;10(6):E170.

151. Lee SY, Shin SJ, Kim HS. ERK1/2 activation mediated by the nutlin3induced mitochondrial translocation of p53. Int J Oncol. 2013;42(3):1027-35.

152. Lee SY, Choi HC, Choe YJ, Shin SJ, Lee SH, Kim HS. Nutlin-3 induces BCL2A1 expression by activating ELK1 through the mitochondrial p53-ROS-ERK1/2 pathway. Int J Oncol. 2014;45(2):675-82.

153. Zhang W, Konopleva M, Burks JK, Dywer KC, Schober WD, Yang JY, et al. Blockade of mitogen-activated protein kinase/extracellular signal-regulated kinase kinase and murine double minute synergistically induces apoptosis in acute myeloid leukemia via BH3-only proteins Puma and Bim. Cancer Res. 2010;70(6):2424-34.

154. Shangary S, Ding K, Qiu S, Nikolovska-Coleska Z, Bauer JA, Liu M, et al. Reactivation of p53 by a specific MDM2 antagonist (MI-43) leads to p21-mediated cell cycle arrest and selective cell death in colon cancer. Mol Cancer Ther. 2008;7(6):1533-42.

155. Valente LJ, Aubrey BJ, Herold MJ, Kelly GL, Happo L, Scott CL, et al. Therapeutic response to non-genotoxic activation of p53 by Nutlin3a is driven by PUMA-mediated apoptosis in lymphoma cells. Cell Rep. 2016;14(8):1858-66.

156. Drakos E, Atsaves V, Schlette E, Li J, Papanastasi I, Rassidakis GZ, et al. The therapeutic potential of p53 reactivation by nutlin-3a in ALK+ anaplastic large cell lymphoma with wild-type or mutated p53. Leukemia. 2009;23(12):2290-9.

157. Saha MN, Jiang $\mathrm{H}$, Chang $\mathrm{H}$. Molecular mechanisms of nutlin-induced apoptosis in multiple myeloma: evidence for p53-transcription-dependent and -independent pathways. Cancer Biol Ther. 2010;10(6):567-78.

158. Koster R, Timmer-Bosscha H, Bischoff R, Gietema JA, de Jong S. Disruption of the MDM2-p53 interaction strongly potentiates p53-dependent apoptosis in cisplatin-resistant human testicular carcinoma cells via the Fas/FasL pathway. Cell Death Dis. 2011;2:e148.

159. Meijer A, Kruyt FA, van der Zee AG, Hollema H, Le P, ten Hoor KA, et al. Nutlin-3 preferentially sensitises wild-type p53-expressing cancer cells to DR5-selective TRAIL over rhTRAlL. Br J Cancer. 2013;109(10):2685-95.

160. Tseng HY, Jiang CC, Croft A, Tay KH, Thorne RF, Yang F, et al. Contrasting effects of nutlin-3 on TRAlL- and docetaxelinduced apoptosis due to upregulation of TRAIL-R2 and Mcl-1 in human melanoma cells. Mol Cancer Ther. 2010;9(12):3363-74.

161. Zauli G, di lasio MG, Secchiero P, Dal Bo M, Marconi D, Bomben R, et al. Exposure of B cell chronic lymphocytic leukemia (B-CLL) cells to nutlin-3 induces a characteristic gene expression profile, which correlates with nutlin3-mediated cytotoxicity. Curr Cancer Drug Targets. 2009;9(4):510-8.

162. Jeay S, Gaulis S, Ferretti S, Bitter H, Ito M, Valat T, et al. A distinct $\mathrm{p} 53$ target gene set predicts for response to the selective p53-HDM2 inhibitor NVP-CGM097. eLife. 2015;4:e06498.

163. Sonkin D. Expression signature based on TP53 target genes doesn't predict response to TP53-MDM2 inhibitor in wild type TP53 tumors. eLife. 2015;4:e10279. 
164. Catizone AN, Good CR, Alexander KA, Berger SL, Sammons MA. Comparison of genotoxic versus nongenotoxic stabilization of p53 provides insight into parallel stress-responsive transcriptional networks. Cell Cycle. 2019;18(8):809-23.

165. Zaccara S, Tebaldi T, Pederiva C, Ciribilli Y, Bisio A, Inga A. p53-directed translational control can shape and expand the universe of p53 target genes. Cell Death Differ. 2014;21(10):1522-34.

166. Haronikova L, Olivares-Illana V, Wang L, Karakostis K, Chen S, Fahraeus R. The p53 mRNA: an integral part of the cellular stress response. Nucleic Acids Res. 2019;47(7):3257-71.

167. Rizzotto D, Zaccara S, Rossi A, Galbraith MD, Andrysik Z, Pandey A, et al. Nutlin-induced apoptosis is specified by a translation program regulated by PCBP2 and DHX30. Cell Rep. 2020;30(13):4355-69 e6.

168. Speidel D. Transcription-independent p53 apoptosis: an alternative route to death. Trends Cell Biol. 2010;20(1):14-24.

169. Steele AJ, Prentice AG, Hoffbrand AV, Yogashangary BC, Hart SM, Nacheva EP, et al. p53-mediated apoptosis of CLL cells: evidence for a transcription-independent mechanism. Blood. 2008;112(9):3827-34.

170. Vaseva AV, Marchenko ND, Moll UM. The transcription-independent mitochondrial p53 program is a major contributor to nutlin-induced apoptosis in tumor cells. Cell Cycle. 2009;8(11):1711-9.

171. Hoffman-Luca CG, Ziazadeh D, McEachern D, Zhao Y, Sun W, Debussche L, et al. Elucidation of acquired resistance to BCl-2 and MDM2 inhibitors in acute leukemia in vitro and in vivo. Clin Cancer Res. 2015;21(11):2558-68.

172. Daver NG, Garcia JS, Jonas BA, Kelly KR, Assouline S, Brandwein JM, et al. Updated results from the venetoclax (Ven) in combination with idasanutlin (Idasa) arm of a phase $1 \mathrm{~b}$ trial in elderly patients (pts) with relapsed or refractory (R/R) AML ineligible for cytotoxic chemotherapy. Blood. 2019;134(Supplement_1):229.

173. Luo Q, Beaver JM, Liu Y, Zhang Z. Dynamics of p53: a master decider of cell fate. Genes (Basel). 2017;8(2):66.

174. Lees A, McIntyre AJ, Crawford NT, Falcone F, McCann C, Holohan C, et al. The pseudo-caspase FLIP(L) regulates cell fate following p53 activation. Proc Natl Acad Sci USA. 2020;117(30):17808-19.

175. Yugawa T, Handa K, Narisawa-Saito M, Ohno S, Fujita M, Kiyono T. Regulation of Notch1 gene expression by p53 in epithelial cells. Mol Cell Biol. 2007;27(10):3732-42.

176. Secchiero P, Melloni E, di lasio MG, Tiribelli M, Rimondi E, Corallini F, et al. Nutlin-3 up-regulates the expression of Notch1 in both myeloid and lymphoid leukemic cells, as part of a negative feedback antiapoptotic mechanism. Blood. 2009;113(18):4300-8.

177. Zhang X, Lin L, Guo H, Yang J, Jones SN, Jochemsen A, et al. Phosphorylation and degradation of MdmX is inhibited by Wip1 phosphatase in the DNA damage response. Cancer Res. 2009;69(20):7960-8.

178. Lu X, Nguyen TA, Zhang X, Donehower LA. The Wip1 phosphatase and Mdm2: cracking the "Wip" on p53 stability. Cell Cycle. 2008;7(2):164-8.

179. Lu X, Nannenga B, Donehower LA. PPM1D dephosphorylates Chk1 and p53 and abrogates cell cycle checkpoints. Genes Dev. 2005;19(10):1162-74.

180. Pechackova S, Burdova K, Benada J, Kleiblova P, Jenikova G, Macurek L. Inhibition of WIP1 phosphatase sensitizes breast cancer cells to genotoxic stress and to MDM2 antagonist nutlin-3. Oncotarget. 2016;7(12):14458-75.

181. Sriraman A, Radovanovic M, Wienken M, Najafova Z, Li Y, Dobbelstein M. Cooperation of Nutlin-3a and a Wip1 inhibitor to induce p53 activity. Oncotarget. 2016;7(22):31623-38.

182. Gasparini C, Tommasini A, Zauli G. The MDM2 inhibitor Nutlin-3 modulates dendritic cell-induced T cell proliferation. Hum Immunol. 2012;73(4):342-5.

183. Sahin I, Zhang S, Navaraj A, Zhou L, Dizon D, Safran H, et al. AMG-232 sensitizes high MDM2-expressing tumor cells to T-cell-mediated killing. Cell Death Discov. 2020;6:57.

184. Guo G, Yu M, Xiao W, Celis E, Cui Y. Local activation of p53 in the tumor microenvironment overcomes immune suppression and enhances antitumor immunity. Cancer Res. 2017;77(9):2292-305.

185. Veneziani I, Infante P, Ferretti E, Melaiu O, Battistelli C, Lucarini V, et al. Nutlin-3a enhances natural killer cellmediated killing of neuroblastoma by restoring p53-dependent expression of ligands for NKG2D and DNAM-1 receptors. Cancer Immunol Res. 2021;9(2):170-83.

186. Li R, Zatloukalova P, Muller P, Gil-Mir M, Kote S, Wilkinson S, et al. The MDM2 ligand Nutlin-3 differentially alters expression of the immune blockade receptors PD-L1 and CD276. Cell Mol Biol Lett. 2020;25:41.

187. Chaplin DD. Overview of the immune response. J Allergy Clin Immunol. 2010;125(2 Suppl 2):S3-23.

188. Fang DD, Tang Q, Kong Y, Wang Q, Gu J, Fang X, et al. MDM2 inhibitor APG-115 synergizes with PD-1 blockade through enhancing antitumor immunity in the tumor microenvironment. J Immunother Cancer. 2019;7(1):327.

189. Klusmann I, Wohlberedt K, Magerhans A, Teloni F, Korbel JO, Altmeyer M, et al. Chromatin modifiers Mdm2 and RNF2 prevent RNA:DNA hybrids that impair DNA replication. Proc Natl Acad Sci USA. 2018;115(48):E11311-20.

190. Frum RA, Singh S, Vaughan C, Mukhopadhyay ND, Grossman SR, Windle B, et al. The human oncoprotein MDM2 induces replication stress eliciting early intra-S-phase checkpoint response and inhibition of DNA replication origin firing. Nucleic Acids Res. 2014;42(2):926-40.

191. Arena G, Cisse MY, Pyrdziak S, Chatre L, Riscal R, Fuentes M, et al. Mitochondrial MDM2 regulates respiratory complex I activity independently of p53. Mol Cell. 2018;69(4):594-609 e8.

192. Arena G, Riscal R, Linares LK, Le Cam L. MDM2 controls gene expression independently of p53 in both normal and cancer cells. Cell Death Differ. 2018;25(9):1533-5.

193. Fahraeus R, Olivares-Illana V. MDM2's social network. Oncogene. 2014;33(35):4365-76.

194. Nicholson J, Hupp TR. The molecular dynamics of MDM2. Cell Cycle. 2010;9(10):1878-81.

195. Ambrosini G, Sambol EB, Carvajal D, Vassilev LT, Singer S, Schwartz GK. Mouse double minute antagonist Nutlin-3a enhances chemotherapy-induced apoptosis in cancer cells with mutant p53 by activating E2F1. Oncogene. 2007;26(24):3473-81.

196. Balint E, Bates S, Vousden KH. Mdm2 binds p73 alpha without targeting degradation. Oncogene. 1999;18(27):3923-9.

197. Lau LM, Nugent JK, Zhao X, Irwin MS. HDM2 antagonist Nutlin-3 disrupts p73-HDM2 binding and enhances p73 function. Oncogene. 2008;27(7):997-1003. 
198. Peirce SK, Findley HW. The MDM2 antagonist nutlin-3 sensitizes p53-null neuroblastoma cells to doxorubicin via E2F1 and TAp73. Int J Oncol. 2009;34(5):1395-402.

199. Rathinavelu A, Narasimhan M, Muthumani P. A novel regulation of VEGF expression by HIF-1alpha and STAT3 in HDM2 transfected prostate cancer cells. J Cell Mol Med. 2012;16(8):1750-7.

200. Zhou S, Gu L, He J, Zhang H, Zhou M. MDM2 regulates vascular endothelial growth factor mRNA stabilization in hypoxia. Mol Cell Biol. 2011;31(24):4928-37.

201. Obacz J, Pastorekova S, Vojtesek B, Hrstka R. Cross-talk between HIF and p53 as mediators of molecular responses to physiological and genotoxic stresses. Mol Cancer. 2013;12(1):93.

202. LaRusch GA, Jackson MW, Dunbar JD, Warren RS, Donner DB, Mayo LD. Nutlin3 blocks vascular endothelial growth factor induction by preventing the interaction between hypoxia inducible factor 1alpha and Hdm2. Cancer Res. 2007:67(2):450-4.

203. Secchiero P, Corallini F, Gonelli A, Dell'Eva R, Vitale M, Capitani S, et al. Antiangiogenic activity of the MDM2 antagonist nutlin-3. Circ Res. 2007;100(1):61-9.

204. Binder BR. A novel application for murine double minute 2 antagonists: the $p 53$ tumor suppressor network also controls angiogenesis. Circ Res. 2007;100(1):13-4.

205. Lee YM, Lim JH, Chun YS, Moon HE, Lee MK, Huang LE, et al. Nutlin-3, an Hdm2 antagonist, inhibits tumor adaptation to hypoxia by stimulating the FlH-mediated inactivation of HIF-1 alpha. Carcinogenesis. 2009;30(10):1768-75.

206. Rinaldo C, Prodosmo A, Siepi F, Moncada A, Sacchi A, Selivanova G, et al. HIPK2 regulation by MDM2 determines tumor cell response to the p53-reactivating drugs nutlin-3 and RITA. Cancer Res. 2009;69(15):6241-8.

207. D'Orazi G, Cecchinelli B, Bruno T, Manni I, Higashimoto Y, Saito S, et al. Homeodomain-interacting protein kinase-2 phosphorylates p53 at Ser 46 and mediates apoptosis. Nat Cell Biol. 2002;4(1):11-9.

208. Rinaldo C, Prodosmo A, Mancini F, lacovelli S, Sacchi A, Moretti F, et al. MDM2-regulated degradation of HIPK2 prevents p53Ser46 phosphorylation and DNA damage-induced apoptosis. Mol Cell. 2007;25(5):739-50.

209. Worrall C, Suleymanova N, Crudden C, Trocoli Drakensjo I, Candrea E, Nedelcu D, et al. Unbalancing p53/Mdm2/ IGF-1R axis by Mdm2 activation restrains the IGF-1-dependent invasive phenotype of skin melanoma. Oncogene. 2017;36(23):3274-86.

210. Girnita L, Girnita A, Brodin B, Xie Y, Nilsson G, Dricu A, et al. Increased expression of insulin-like growth factor I receptor in malignant cells expressing aberrant p53: functional impact. Cancer Res. 2000;60(18):5278-83.

211. Girnita L, Girnita A, Larsson O. Mdm2-dependent ubiquitination and degradation of the insulin-like growth factor 1 receptor. Proc Natl Acad Sci USA. 2003;100(14):8247-52.

212. Chng WJ, Gualberto A, Fonseca R. IGF-1R is overexpressed in poor-prognostic subtypes of multiple myeloma. Leukemia. 2006;20(1):174-6.

213. Kucab JE, Dunn SE. Role of IGF-1R in mediating breast cancer invasion and metastasis. Breast Dis. 2003:17:41-7.

214. Girnita L, Shenoy SK, Sehat B, Vasilcanu R, Girnita A, Lefkowitz RJ, et al. \{beta\}-Arrestin is crucial for ubiquitination and down-regulation of the insulin-like growth factor-1 receptor by acting as adaptor for the MDM2 E3 ligase. J Biol Chem. 2005;280(26):24412-9.

215. Davaadelger B, Perez RE, Zhou Y, Duan L, Gitelis S, Maki CG. The IGF-1R/AKT pathway has opposing effects on Nutlin-3a-induced apoptosis. Cancer Biol Ther. 2017;18(11):895-903.

216. Rubio-Patino C, Trotta AP, Chipuk JE. MDM2 and mitochondrial function: one complex intersection. Biochem Pharmacol. 2019;162:14-20.

217. Way L, Faktor J, Dvorakova P, Nicholson J, Vojtesek B, Graham D, et al. Rearrangement of mitochondrial pyruvate dehydrogenase subunit dihydrolipoamide dehydrogenase protein-protein interactions by the MDM2 ligand nutlin-3. Proteomics. 2016;16(17):2327-44.

218. Elkholi R, Abraham-Enachescu I, Trotta AP, Rubio-Patino C, Mohammed JN, Luna-Vargas MPA, et al. MDM2 integrates cellular respiration and apoptotic signaling through NDUFS1 and the mitochondrial network. Mol Cell. 2019;74(3):452-65 e7.

219. Ha JH, Won EY, Shin JS, Jang M, Ryu KS, Bae KH, et al. Molecular mimicry-based repositioning of nutlin-3 to antiapoptotic Bcl-2 family proteins. J Am Chem Soc. 2011;133(5):1244-7.

220. Verma R, Rigatti MJ, Belinsky GS, Godman CA, Giardina C. DNA damage response to the Mdm2 inhibitor nutlin-3. Biochem Pharmacol. 2010;79(4):565-74.

221. Carrillo AM, Bouska A, Arrate MP, Eischen CM. Mdmx promotes genomic instability independent of p53 and Mdm2. Oncogene. 2015;34(7):846-56.

222. Carrillo AM, Hicks M, Khabele D, Eischen CM. Pharmacologically increasing Mdm2 inhibits DNA repair and cooperates with genotoxic agents to kill p53-inactivated ovarian cancer cells. Mol Cancer Res. 2015;13(8):1197-205.

223. Supiot S, Hill RP, Bristow RG. Nutlin-3 radiosensitizes hypoxic prostate cancer cells independent of p53. Mol Cancer Ther. 2008;7(4):993-9.

224. Zheng T, Yin D, Lu Z, Wang J, Li Y, Chen X, et al. Nutlin-3 overcomes arsenic trioxide resistance and tumor metastasis mediated by mutant p53 in hepatocellular carcinoma. Mol Cancer. 2014;13:133.

225. Lee DM, Kim IY, Seo MJ, Kwon MR, Choi KS. Nutlin-3 enhances the bortezomib sensitivity of p53-defective cancer cells by inducing paraptosis. Exp Mol Med. 2017;49(8):e365.

226. Yeldag G, Rice A, Del Rio HA. Chemoresistance and the self-maintaining tumor microenvironment. Cancers (Basel). 2018;10(12):471.

227. Wicki A, Mandala M, Massi D, Taverna D, Tang H, Hemmings BA, et al. Acquired resistance to clinical cancer therapy: a twist in physiological signaling. Physiol Rev. 2016;96(3):805-29.

228. Stuhmer T, Chatterjee M, Hildebrandt M, Herrmann P, Gollasch H, Gerecke C, et al. Nongenotoxic activation of the p53 pathway as a therapeutic strategy for multiple myeloma. Blood. 2005;106(10):3609-17.

229. Aziz MH, Shen H, Maki CG. Acquisition of p53 mutations in response to the non-genotoxic p53 activator Nutlin-3. Oncogene. 2011;30(46):4678-86.

230. Shen H, Maki CG. Persistent p21 expression after Nutlin-3a removal is associated with senescence-like arrest in $4 \mathrm{~N}$ cells. J Biol Chem. 2010;285(30):23105-14. 
231. Shen H, Moran DM, Maki CG. Transient nutlin-3a treatment promotes endoreduplication and the generation of therapy-resistant tetraploid cells. Cancer Res. 2008;68(20):8260-8.

232. Sharom FJ. The P-glycoprotein multidrug transporter. Essays Biochem. 2011;50(1):161-78.

233. Grigoreva T, Sagaidak A, Romanova A, Novikova D, Garabadzhiu A, Tribulovich V. Establishment of drug-resistant cell lines under the treatment with chemicals acting through different mechanisms. Chem Biol Interact. 2021;344:109510.

234. Michaelis M, Rothweiler F, Barth S, Cinatl J, van Rikxoort M, Loschmann N, et al. Adaptation of cancer cells from different entities to the MDM2 inhibitor nutlin-3 results in the emergence of p53-mutated multi-drug-resistant cancer cells. Cell Death Dis. 2011;2:e243.

235. Skalniak L, Kocik J, Polak J, Skalniak A, Rak M, Wolnicka-Glubisz A, et al. Prolonged idasanutlin (RG7388) treatment leads to the generation of p53-mutated cells. Cancers (Basel). 2018;10(11):396.

236. Michaelis M, Rothweiler F, Agha B, Barth S, Voges Y, Loschmann N, et al. Human neuroblastoma cells with acquired resistance to the p53 activator RITA retain functional p53 and sensitivity to other p53 activating agents. Cell Death Dis. 2012;3:e294.

237. Berberich A, Kessler T, Thome CM, Pusch S, Hielscher T, Sahm F, et al. Targeting resistance against the MDM2 inhibitor RG7388 in glioblastoma cells by the MEK inhibitor trametinib. Clin Cancer Res. 2019;25(1):253-65.

238. Deben CBL, Domen A, Wouters A, Cuypers B, Laukens K, Lardon F, Pauwels P. Characterization of acquired nutlin-3 resistant non-small cell lung cancer cells. Cancer Drug Resist. 2021;4:233-43.

239. Gonzalez H, Hagerling C, Werb Z. Roles of the immune system in cancer: from tumor initiation to metastatic progression. Genes Dev. 2018;32(19-20):1267-84.

240. Hata AN, Rowley S, Archibald HL, Gomez-Caraballo M, Siddiqui FM, Ji F, et al. Synergistic activity and heterogeneous acquired resistance of combined MDM2 and MEK inhibition in KRAS mutant cancers. Oncogene. 2017;36(47):6581-91.

241. Drummond CJ, Esfandiari A, Liu J, Lu X, Hutton C, Jackson J, et al. TP53 mutant MDM2-amplified cell lines selected for resistance to MDM2-p53 binding antagonists retain sensitivity to ionizing radiation. Oncotarget. 2016;7(29):46203-18.

242. Hoffman-Luca CG, Yang CY, Lu J, Ziazadeh D, McEachern D, Debussche L, et al. Significant differences in the development of acquired resistance to the MDM2 inhibitor SAR405838 between in vitro and in vivo drug treatment. PLOS ONE. 2015;10(6):e0128807.

243. Marcellino BK, Farnoud N, Cassinat B, Lu M, Verger E, McGovern E, et al. Transient expansion of TP53 mutated clones in polycythemia vera patients treated with idasanutlin. Blood Adv. 2020;4(22):5735-44.

\section{Publisher's Note}

Springer Nature remains neutral with regard to jurisdictional claims in published maps and institutional affiliations.

- fast, convenient online submission

- thorough peer review by experienced researchers in your field

- rapid publication on acceptance

- support for research data, including large and complex data types

- gold Open Access which fosters wider collaboration and increased citations

- maximum visibility for your research: over $100 \mathrm{M}$ website views per year

At BMC, research is always in progress.

Learn more biomedcentral.com/submissions 